\title{
Salt Stress Tolerance in Rice: Emerging Role of Exogenous Phytoprotectants
}

\author{
Anisur Rahman, Kamrun Nahar, \\ Jubayer Al Mahmud, Mirza Hasanuzzaman, \\ Md. Shahadat Hossain and Masayuki Fujita \\ Additional information is available at the end of the chapter
}

http://dx.doi.org/10.5772/67098

\begin{abstract}
Excess salinity in soil is one of the major environmental factors that limit plant growth and yield of a wide variety of crops including rice. On the basis of tolerance ability toward salinity, rice is considered as salt-sensitive crop, and growth and yield of rice are greatly affected by salinity. In general, rice can tolerate a small amount of saltwater without compromising the growth and yield. However, it greatly depends on the types and species of rice and their growth stage. Salinity-induced ionic and osmotic stresses reduce rate of photosynthesis and consequently cause oxidative stress, which is also responsible for growth reduction. The negative effects of salt stress that mentioned ultimately reduced yield of most crops including rice, except some halophytes. In recent decades, researchers have developed various approaches toward making salt-tolerant rice varieties. Using phytoprotectants is found to be effective in conferring salt tolerance to rice plants. In this chapter, we reviewed the recent reports on different aspects on salt stress tolerance strategies in light of using phytoprotectants.
\end{abstract}

Keywords: Oryza sativa, abiotic stress, oxidative stress, ROS, phytohormones, calcium

\section{Introduction}

In a changing world, plants experience various kinds of environmental stresses (salinity, drought, heat, cold, flooding, heavy metals, ozone, UV radiation, etc.), which affect plant growth, yield and productivity that challenges the food security of ever-growing population all over the world $[1,2]$. Of the environmental factors, salinity is one of the most brutal abiotic stresses, because most crop plants are sensitive to salt stress $[1,3,4]$. The condition of soil characterized by high concentrations of soluble salt is called salinity. About $6 \%$ of world's total land area and one-third of world's irrigated land area are affected by salinity directly or by secondary salinity. Among 
the cultivable area, $20 \%$ of irrigated land and $2 \%$ of the dry land area are affected by salinity directly or by secondary salinity [5]. The problem of salinization is increasing day by day, often due to bad agricultural practices and climate changes. It is assumed that $50 \%$ of the cultivable land will be salt affected by the middle of the twenty-first century [6].

Excess salinity in soil is one of the major environmental factors that limit growth and yield of a wide variety of crops including rice $[3,4,7]$. Many studies revealed the negative effect of salinity on plant growth, development and yield [8-13]. The damages by higher salinity in plant start from germination and exist till death of plant [13]. It is evident that salt stress has negative correlation with seed germination and vigor of wide variety of crops [3]. In the seedling stage, salt stress affects plant growth by osmotic and ionic stress. Salinity-induced ionic and osmotic stresses reduce rate of photosynthesis and consequently cause oxidative stress, which is also responsible for growth reduction $[3,4,14]$. The negative effects of salt stress that mentioned ultimately reduced yield of most crops including rice, except some halophytes.

On the basis of tolerance ability toward salinity, rice is considered as salt-sensitive crop, and growth and yield of rice are greatly affected by salinity [12]. Salinity-induced yield reduction of rice is alarming for the food security of ever-growing population of the world, especially in Asia, because $90 \%$ of the world's rice is produced and consumed in Asia and more than 3 billions of Asian intake their $50-80 \%$ daily calorie from rice [15]. So, it is an urgent task of plant biologists to develop salt-tolerant rice cultivar to ensure food security of rising population, since expansion of rice-growing areas is limited because of industrialization and various stresses including salinity [16].

Along with developing tolerant cultivar by breeding and genetic engineering, detoxification of reactive oxygen species (ROS) and methylglyoxal (MG), maintenance of nutrient homeostasis and reduction of salt uptake comprise some stress tolerance mechanisms within the plant under salt stress condition [11, 14, 17, 19]. Considering the factors that discussed, use of exogenous phytoprotectants become one of the important approaches for improving salt stress tolerance by osmoregulation, ROS and MG detoxification and ion homeostasis in rice [11, 14, $17,18]$. Considering the above-mentioned factors, in this chapter, we discuss salinity-induced damages and alleviation of salt stress by using exogenous phytoprotectants in rice plant.

\section{Effect of salinity on rice plants}

Soil salinity is not a new problem for rice production. In the coastal area, rice has been growing in saline soils since long time. The adjacent rivers, canals, streams and other water bodies are always contaminated with salt to a certain extent. With the initiation of green revolution, most of the rice production is being depending on irrigation water and salt intrusion in coastal areas becomes a common phenomenon recently. In general, rice can tolerate a small amount of saltwater without compromising the growth and yield. However, it greatly depends on the types and species of rice and their growth stage [3]. Lee et al. [19] reported that the tolerance level of indica is higher than that of japonica at seedlings stage. At early stage of growth, rice is grouped as salinity susceptible cereal and confines its efficiency of production at mature stage [20,21]. According to IRRI [22], soil salinity beyond EC $\sim 4 \mathrm{dS} \mathrm{m}^{-1}$ is considered as moderate salinity for rice, while more than $8 \mathrm{dS} \mathrm{m}^{-1}$ is high. However, it is not absolute measure, and it depends 
on other soil factors because they are interacted with each other. Excess salt caused both ionic toxicity and osmotic stress in rice plants. Under high salinity, rice plants show various morphological, physiological or biochemical alterations and symptoms and even may die when the salt stress becomes very high (Figure 1). Sodium ion itself causes direct cellular injury to plants, and additionally, higher amount of $\mathrm{Na}^{+}$in root zone inhibits $\mathrm{K}^{+}$uptake because of their antagonistic effect [23]. This shortage of $\mathrm{K}^{+}$inside the cell unavoidably leads to decrease in plant growth because $\mathrm{K}^{+}$has vital role in preserving membrane potential, enzyme activities and cell turgor [21,23]. Apart from $\mathrm{Na}^{+}$or other anions, some of the cations like $\mathrm{Cl}^{-}$also show toxicity in rice. Ionic stress causes chlorosis and necrosis which either accelerate senescence or impair growth and development. Due to the excess accumulation of $\mathrm{Na}^{+}$in the cytoplasm during $\mathrm{NaCl}$ salinity, cellular metabolisms such as protein synthesis and enzyme activities are hampered, and therefore, source-sink relationship and photosynthesis are disrupted [24]. Many reports showed that $\mathrm{Na}^{+}$accumulation in shoots is relatively well correlated with the survival of rice plants under salinity stress [24], and hence, keeping a lower cytosolic $\mathrm{Na}^{+}$is considered as one of the vital strategies for salt tolerance in glycophytes [24]. As a result of salinity-induced osmotic stress, water uptake by plant is hampered and plant suffers from physiological drought. This also led to the interruption of nutrient uptake. Under osmotic stress, regulation of water transport becomes a vital adaptive strategy of rice plants because a sufficient amount of water is indispensable for the cells to maintain their growth and vital cellular functions such as photosynthesis and metabolisms. This situation also induces stomatal closure, which results in the reduction of evaporation and water transport. A set of hormonal regulations also associated with these processes is upregulated many-fold under salt stress [24]. In the next subsections, we provided a description of the specific responses of plants under salinity.

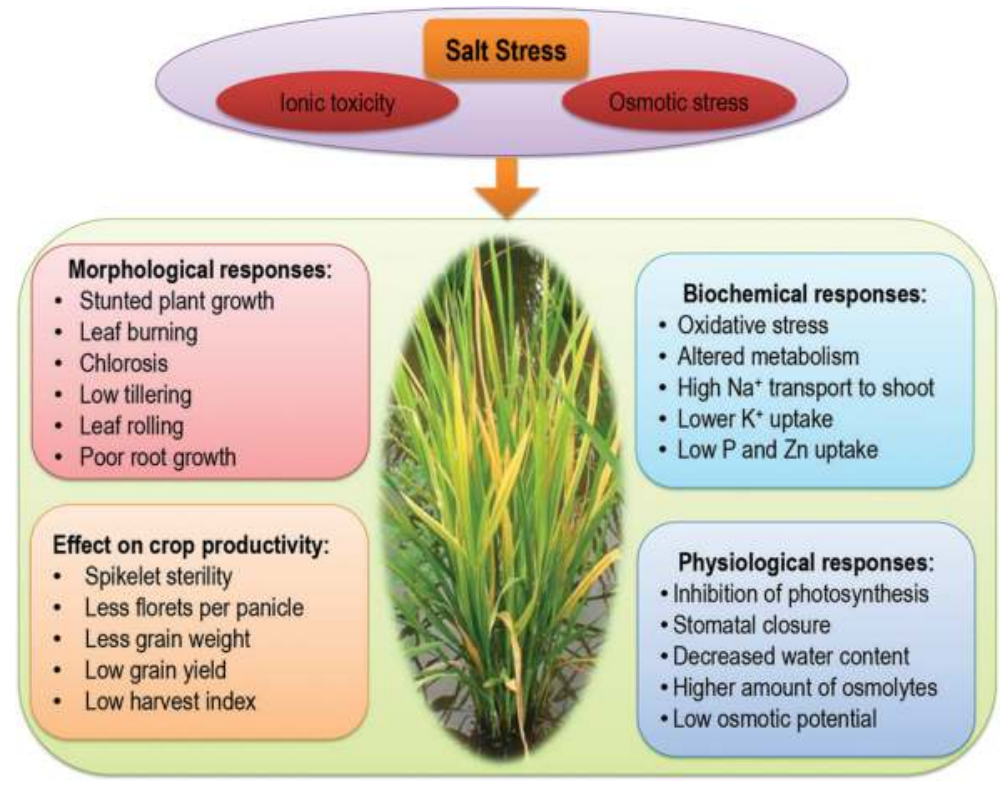

Figure 1. Salinity-induced major responses in rice plants. 


\subsection{Seed germination}

Germination of seed is the starting and one of the most important phases of plant life cycle that determines the better establishment of seedlings as well as growth, development and yield of plant. It is well documented that the presence of salt in germination media hampers germination and seedling establishment by osmotic and ionic stress [3]. Salinity hampers seed germination by affecting major events of germination such as imbibition, metabolism activation, emergence of embryonic tissues and seedling establishment [4, 25]. Salinity-induced osmotic and ionic stresses inhibit and delay seed germination by limiting hydrolysis of seed through water imbalance, cell membrane destruction and enzyme activity reduction. Poor hydrolysis also limits translocation of food reserve from storage tissue to develop embryo that also negatively affects germination and seedling establishment. Salinity inhibits amylase activity, which is the major reason of poor hydrolysis or imbibitions of stored substances [26]. However, the negative effect of salinity on seed germination may vary due to various factors, such as varietal variation, level of salinity and other external factors [4]. Like other crop plants, rate of germination, speed of germination and seedling establishment of rice are greatly affected by salinity [26, 28]. Many studies revealed that salinity reduces germination percentage, germination index, germination speed, germination energy percentage (GE\%) and mean germination time along with seedlings establishment in rice. Rajakumar [29] reported that salinity decreased germination percentage gradually with the increase of salt stress $(0-300 \mathrm{mM} \mathrm{NaCl})$ by higher accumulation of proline (Pro) and lower starch and protein content. Higher salinity (100 and $200 \mathrm{mM})$ delayed germination (3-6 days) and decreased germination percentages (upto 61\%) by increasing solute leakage and decreasing $\alpha$-amylase activity [30]. Islam and Karim [31] reported that germination percentage and germination index decreased in 17 rice genotypes with increasing the level of salinity in germination media. Germination percentage and mean germination time decreased in six rice genotypes with increasing the concentration of salinity [32]. Kazemi and Eskandari [33] observed the effect of salinity $\left(0-8 \mathrm{dS} \mathrm{m}^{-1}\right)$ on three rice cultivars (Anbar, LD and Hamar) and reported that salinity decreased germination percentage (up to $96 \%$ ), germination speed, and plumule and radical growth with increasing the level of salinity. Effect of six levels of salinity $\left(0-20 \mathrm{dS} \mathrm{m}^{-1}\right)$ was studied by Hakim et al. [28] on 12 rice cultivars and noticed that the level of damage on seed germination and early seedling growth increased with increasing the level of salinity. They found that salinity decreased germination percentage, speed of germination and GE\% up to 88,99 and $100 \%$, respectively, with highest level of salinity $\left(20 \mathrm{dS} \mathrm{m}^{-1}\right)$. Ologundudu et al. [34] also found that germination percentage, speed of germination and GE\% decreased in eight rice cultivars under different

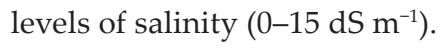

\subsection{Plant growth}

It is well documented that seedling and early vegetative growth stages are most susceptible to salinity during the entire life cycle of plant $[3,4]$. On the basis of tolerance ability, rice is saltsensitive crop and the sensitivity to salinity varies with the growth stages. Among the growth stages, early seedling stages of rice are also considered as most sensitive to salinity compared with other stages [35]. Aref [36] subjected rice plant to salinity at tillering, panicle initiation, 
panicle emergence and ripening stage where salt-induced damages were higher at tillering and panicle initiation stages compared with other two stages.

The immediate response of plant seedlings to high concentration of salt around the root is osmotic effect that reduces water uptake capacity. Osmotic stress disturbs the water balance and causes water loss from the cell that gradually reduces cell elongation, cell division, stomatal closure and leaf area as well as photosynthesis and growth $[3,5]$. The presence of high concentration of salt $(\mathrm{NaCl})$ around the root zone also reduces plant growth by ionic toxicity through over accumulation of $\mathrm{Na}^{+}$and $\mathrm{Cl}^{-}$. In addition, $\mathrm{Na}^{+}$influx causes chlorosis, necrosis and premature senescence of adult leaves and thus limits the photosynthetic area available to support continued growth of salt-affected plants [5, 16, 37]. In later stage, salt-induced ionic and osmotic stresses and lower rate of photosynthesis cumulatively cause oxidative stress by overproduction of ROS, which is also responsible for growth reduction under salt stress condition $[3,12]$.

However, many studies revealed the salt-induced growth reduction in rice. Exposure of higher salinity $(150 \mathrm{mM} \mathrm{NaCl})$ in rice seedlings reduces plant height and biomass by saltinduced osmotic, ionic and oxidative stresses [17]. Rahman et al. [18] also reported that salt stress $(200 \mathrm{mM} \mathrm{NaCl})$ reduced plant growth by creating ionic and water imbalance, and oxidative stress. Salt-induced growth reduction by oxidative stress in rice seedlings was also reported by Özdemir et al. [27]. Under salt stress condition, growth reduction and water loss were higher in susceptible cultivar compared with tolerant cultivar [3, 31]. Kumar and Khare [38] found that salt stress $\left(100 \mathrm{mM} \mathrm{NaCl} \approx 10 \mathrm{dS} \mathrm{m} \mathrm{m}^{-1}\right)$ reduced root length, root dry weight, shoot length and shoot dry weight both in sensitive and in tolerant cultivar where growth reduction is higher in sensitive cultivar compared with tolerant. On the other hand, growth of rice seedlings decreased with increasing the level of salinity [31, 33]. Ologundudu et al. [34] conducted experiment with eight rice cultivars under different level of salinity $\left(0-15 \mathrm{dS} \mathrm{m}^{-1}\right)$ and reported that root and shoot length, root and shoot dry weight, and total dry matter production decreased with increasing the level of salinity.

\subsection{Physiological attributes}

Among different physiological processes, photosynthesis is a vital physiological attribute related to plant growth and development that is affected by salinity. Photosynthesis is a complex process depending on gas-exchange characteristics, photosynthetic pigments, photosystems, components of electron transport system and activities of different enzymes involved in carbon metabolism. Therefore, damage to any of those components affects photosynthesis negatively [39, 40]. Rate of photosynthesis declines under saline condition primarily due to osmotic stress that results in stomatal closure and secondarily by higher accumulation of $\mathrm{Na}^{+}$and $\mathrm{Cl}^{-}$that can damage thylakoid membrane in the choloroplast [3] Salinity-induced limitation of $\mathrm{CO}_{2}$ diffusion causes inactivation of RuBisCo. Moradi et al. [41] demonstrated a remarkable decrease in photosynthetic $\mathrm{CO}_{2}$ fixation, transpiration and stomatal conductance (gs) in three rice cultivars due to salt stress. Salt-sensitive genotype IR29 showed greater reduction of these attributes than tolerant genotypes IR652 and IR632. In another study, Cha-um et al. [42] reported that in dark reaction, net photosyn- 
thetic rate (NPR), gs and transpiration rate (E) decreased in both varieties, Homjan (HJ) and Pathumthani 1 (PT1) varieties, under salt-stressed condition. Photosynthetic pigments, chl $a$ and chl $b$, are greatly affected by different abiotic stresses including salinity. Accumulation of toxic $\mathrm{Na}^{+}$reduces the content of precursor of chl biosynthesis (such as glutamate and 5-aminolevullinic acid) and thus interrupts chl biosynthesis under saline condition [40]. Salinityinduced chlorophyll (chl) reduction is observed in rice like other crops. Amirjani [43] found a dose-dependent reduction of chl content against salt stress $(0,25,50,100$ and $200 \mathrm{mM} \mathrm{NaCl})$. At $200 \mathrm{mM} \mathrm{NaCl}$, chl $a$ and chl $b$ reduced by 44 and 27\%, respectively, compared to control. Rahman et al. [17] reported that 12-day-old rice seedlings exposed to $150 \mathrm{mM} \mathrm{NaCl}$ for 3 days caused 23 and $19 \%$ reduction in chl $a$ and chl $b$, respectively, compared to control. As the duration of salt stress extended for further 3 days, chl $a$ and chl $b$ reduced by 46 and $48 \%$, compared to control.

Reduction of photosynthesis due to stomatal closure and subsequent $\mathrm{CO}_{2}$ shortage affects source to sink translocation of photosynthates and carbohydrate metabolism in leaves. Photosynthates may contribute to salt stress tolerance by serving as osmolytes. Pattanagul and Thitisaksakul [44] observed carbohydrate metabolism in salt-tolerant and salt-susceptible rice genotypes. They mentioned increased total soluble sugar and sucrose content in susceptible genotype under salt stress, while starch accumulation increased in salt-tolerant genotype. To explain this result, they assumed that salt-susceptible rice genotype could not use carbohydrate for plant growth, thus growth reduced and total soluble sugar and sucrose content increased.

\subsection{Osmotic stress}

Salt stress imposes hyperosmotic stress in plants. Osmotic stress is physiological dysfunction resulted from alteration of solute concentration around a cell. Salt imposition in the growing media increases solute concentration around the root zone and lowering of the soil water potential for which plants cannot uptake water as a result plants suffer from osmotic stress. Salt-induced osmotic stress is often termed as physiological drought which is accountable for physiological disorders and injuries within the plants $[45,46]$. Several research findings demonstrated osmotic stress and its damage effects induced by salinity. Osmotic potentials in roots and in the oldest and youngest leaves were measured. Salt-resistant cultivars (Nona Bokra and IR 4630) were characterized by lower osmotic potential, in contrast to the salt-sensitive cultivars (I Kong Pao and IR 3 1785) [47]. Redillas et al. [48] reported that trehalose (Tre) producing transgenic Oryza sativa expressing TPSP (Ubi1:TPSP) accumulated more Tre under salt stress and showed less osmotic stress, in contrast to nontransgenic cultivar. Two rice cultivars [IR651 (salt-tolerant) and IR29 (salt-sensitive)] were grown under salt stress $(100 \mathrm{mM} \mathrm{NaCl})$, where total soluble sugars accumulation was higher in shoot of tolerant cultivar, compared to sensitive cultivar. Increased total soluble sugar was suggested to regulate osmotic potential and water uptake capacity under salt stress [49]. Starch degradation and sugar accumulation were also reported in salt-affected rice plant and described as a strategy to improve osmotic status and plant survival. Salt-sensitive rice cultivar (Pathumthani 1) showed lower starch degradation and reduced sugar accumula- 
tion, compared to Homjan (salt-tolerant cultivar expressing starch metabolism related genes, AGPL1, AGPS2b and SBEIIb) under salt stress (150 mM NaCl, 7 days). Water use efficiency of Pathumthani 1 significantly reduced by $35 \%$, whereas water use efficiency in salt-tolerant cultivar did not change. Starch metabolism capacity of sensitive cultivar was lower in saltsensitive cultivar that decreased the water use efficiency [50]. Salt stress due to lowering the soil water potential causes reduction of water uptake and as a secondary effect stomata closes. This stomatal closure reduces $\mathrm{CO}_{2}$ availability and fixation which reduce photosynthesis [51]. Reduction of tissue water content, modulation of osmotic potential and accumulation of compatible solutes are the most common indications of salt-induced osmotic stress as studied in several research findings. Two different levels of salt stresses (150 and $300 \mathrm{mM} \mathrm{NaCl}, 48 \mathrm{~h}$ ) were imposed to two different cultivars of rice, namely BRRI dhan 49 and BRRI dhan54. Salt stress imposition decreased leaf RWC and increased Pro content in both cultivars. Being a salt-sensitive cultivar, BRRI dhan49 showed decrease in leaf RWC by 19 and $29 \%$, under 150 and $300 \mathrm{mM}$ salt stresses, whereas in salt-tolerant cultivar BRRI dhan54, RWC decreased by 12 and $28 \%$ under 150 and $300 \mathrm{mM} \mathrm{NaCl}$ stress, respectively, compared to control [14]. Cha-Um and Kirdmanee [42] observed decreased water use efficiency in salt-sensitive rice cultivar exposed to salt $(150 \mathrm{mM} \mathrm{NaCl})$ stress. The KDML105 rice callus was grown in salt $(250 \mathrm{mM} \mathrm{NaCl})$ containing media for 2, 4, 6, 8 and 10 days. With the increase of salt stress duration, the water content of rice cells progressively decreased. Salt stress increased accumulation of Pro. The Pro content increased with the increase of duration of stress. Proline level reached to the highest level at the 10th day of salt stress [52]. Rahman et al. [18] reported reduction of leaf RWC and increase of Pro as stress marker due to exposure of rice (Oryza sativa L. cv. BRRI dhan47) seedlings to $200 \mathrm{mM} \mathrm{NaCl}$ stress. Rice cultivars differing in salt tolerance capacity were subjected to different levels of salt stresses $(20,30$, 40 or $50 \mathrm{mM} \mathrm{NaCl}$ ) [47].

\subsection{Ionic toxicity/imbalance}

Salt stress generally involves with ionic toxicity/injury, and a high salt content in the growing media is able to break the ion homeostasis, destroy the ionic balance and induce nutritional disorder in plant cells [53]. The nutritional disorders may be associated with the effect of salinity on nutrient availability, competitive uptake, distribution or transport within the plant [2]. Generally, $\mathrm{Na}^{+}, \mathrm{K}^{+}, \mathrm{Ca}^{2+}, \mathrm{Mg}^{2+}, \mathrm{Cl}^{-}$and sometimes $\mathrm{SO}_{4}{ }^{2-}$ and $\mathrm{CO}_{3}{ }^{2-}$ ions are responsible for salinization. As $\mathrm{Na}^{+}$predominates in the soils, the common problem for crop production is soil sodicity. In addition, sodic soils are important because they create very poor soil structure due to disaggregation of soil properties which impair water movement [3]. So, most of the plant researches focuses on the transport mechanism of $\mathrm{Na}^{+}$ion and its action to the plant cell. The ionic imbalances, which are developed by the accumulation of toxic ions, such as $\mathrm{Na}^{+}$and $\mathrm{Cl}^{-}$, and the depletion of ions, such as $\mathrm{K}^{+}$and $\mathrm{Ca}^{2+}$, are directly affected by salinity [54]. The maintenance of $\mathrm{Na}^{+}$and $\mathrm{K}^{+}$homeostasis becomes more vital under salt stress. Plant exposed to salt stress is affected by $\mathrm{Na}^{+}$influx, which causes $\mathrm{K}^{+}$efflux and triggers $\mathrm{K}^{+}$and $\mathrm{Ca}^{2+}$ leakage from plant cells because plants uptake higher amount of $\mathrm{Na}^{+}$and show increasing $\mathrm{Na}^{+} / \mathrm{K}^{+}$ratio $[17,18$, 55]. Entrance and accumulation of $\mathrm{Na}^{+}$to a high level become toxic to many enzymes because it competes with $\mathrm{K}^{+}$for binding sites of important enzymes [56]. Moreover, $\mathrm{Na}^{+}$influx causes 
chlorosis and necrosis in adult leaves and premature senescence of mature leaves by upsetting protein synthesis and interfering with enzyme activity $[5,57]$. Micronutrient deficiencies are very common under salt stress because the availability of micronutrients in saline soils is dependent on its solubility, $\mathrm{pH}$ and redox potential of the soil solution and the nature of binding sites on the inorganic and organic particle surfaces [58]. Rahman et al. [18] carried out an experiment with rice plant and found $\mathrm{NaCl}$-induced stress disturbed ion homeostasis through increase of $\mathrm{Na}^{+}$content and decreased of $\mathrm{K}^{+}$content in the shoots and roots of rice seedlings, which might be due to entrance of higher amount of $\mathrm{Na}^{+}$into plant by nonselective cation channel (NSCC) that caused $\mathrm{K}^{+}$efflux or leakage through NSCC and guard cell outward rectifying potassium channels (GORK). Importantly, they reported that higher $\mathrm{Na}^{+}$accumulation also resulted in a higher $\mathrm{Na}^{+} / \mathrm{K}^{+}$ratio which disrupted homeostasis by decreasing $\mathrm{Mg}$, Mn and $\mathrm{Zn}$ contents. In rice, substantial variation in uptake and accumulation of $\mathrm{Na}^{+}$between genotypes was repeatedly observed, and tolerant genotypes tended to accumulate less $\mathrm{Na}^{+}$and maintain higher ratios of $\mathrm{K}^{+} / \mathrm{Na}^{+}$and $\mathrm{Ca}^{2+} / \mathrm{Na}^{+}$in plant tissues under salt stress [5, 59]. Azarin et al. [60] demonstrated that salt treatment strongly stimulated accumulations of $\mathrm{Na}^{+}, \mathrm{Na}^{+} / \mathrm{K}^{+}$ratio, $\mathrm{Cl}^{-}$in root and shoot and reduced $\mathrm{K}^{+}, \mathrm{NO}_{3}^{-}$contents in both organs under $1.2 \% \mathrm{NaCl}$ stress condition. They also stated that $\mathrm{Cl}^{-}$ions negatively affected the biomass growth and survival of rice plants. So, it can be concluded that salinity initially causes disruption of ion homeostasis and increases ionic toxicity and nutritional disorder in plant by increasing $\mathrm{Na}^{+}$and $\mathrm{Cl}^{-}$uptake which finally hampers the growth and development of rice plant.

\subsection{Oxidative stress}

One of the common consequences of salt stresses in plant is the accelerated production of ROS [51]. Exposure of plant to high salinity induces closure of stomata. As a result, $\mathrm{CO}_{2}$ availability as well as fixation in the leaf tissues becomes reduced. At the same time, a decreased reduction of $\mathrm{CO}_{2}$ by Calvin cycle and a state of excessive excitation energy occur, of which chloroplasts become exposed, and sequentially, photosynthetic electron transport system becomes impaired. Thus, salinity causes the excessive synthesis of ROS including superoxide $\left(\mathrm{O}_{2}{ }^{--}\right)$, singlet oxygen $\left({ }^{1} \mathrm{O}_{2}\right)$, hydroxyl radicals $(\mathrm{OH} \bullet)$ and hydrogen peroxide $\left(\mathrm{H}_{2} \mathrm{O}_{2}\right)$ and results in oxidative stress $[3,4,61]$. A water deficit condition also occurs under salinity which further contributes to the generation of ROS [62]. In plant cells, ROSs are continuously produced as a consequence of aerobic metabolism in all the intracellular organelles, particularly in chloroplast, mitochondria and peroxisomes [63] (Figure 2). The reduction of the $\mathrm{CO}_{2} / \mathrm{O}_{2}$ ratio of chloroplast increases the synthesis of $\mathrm{H}_{2} \mathrm{O}_{2}$ by accelerating the photorespiration process [64]. These ROSs are very reactive in nature and interfere with plants normal metabolism by causing the peroxidation of lipid, oxidation of protein, nucleic acid and DNA [65]. However, plants try to detoxify ROS by their well-established antioxidant defense system, which includes both the enzymatic antioxidants, that is, catalase (CAT), superoxide dismutase (SOD), ascorbate peroxidase (APX), monodehydroascorbate reductase (MDHAR), dehydroascorbate reductase (DHAR), glutathione $S$-transferase (GST) and glutathione reductase (GR), and nonenzymatic antioxidants, that is, glutathione (GSH), ascorbate (AsA), tocopherols and carotenoids [2]. These act coordinately in scavenging ROS and protecting cells from oxidative stress $[2,9]$. 


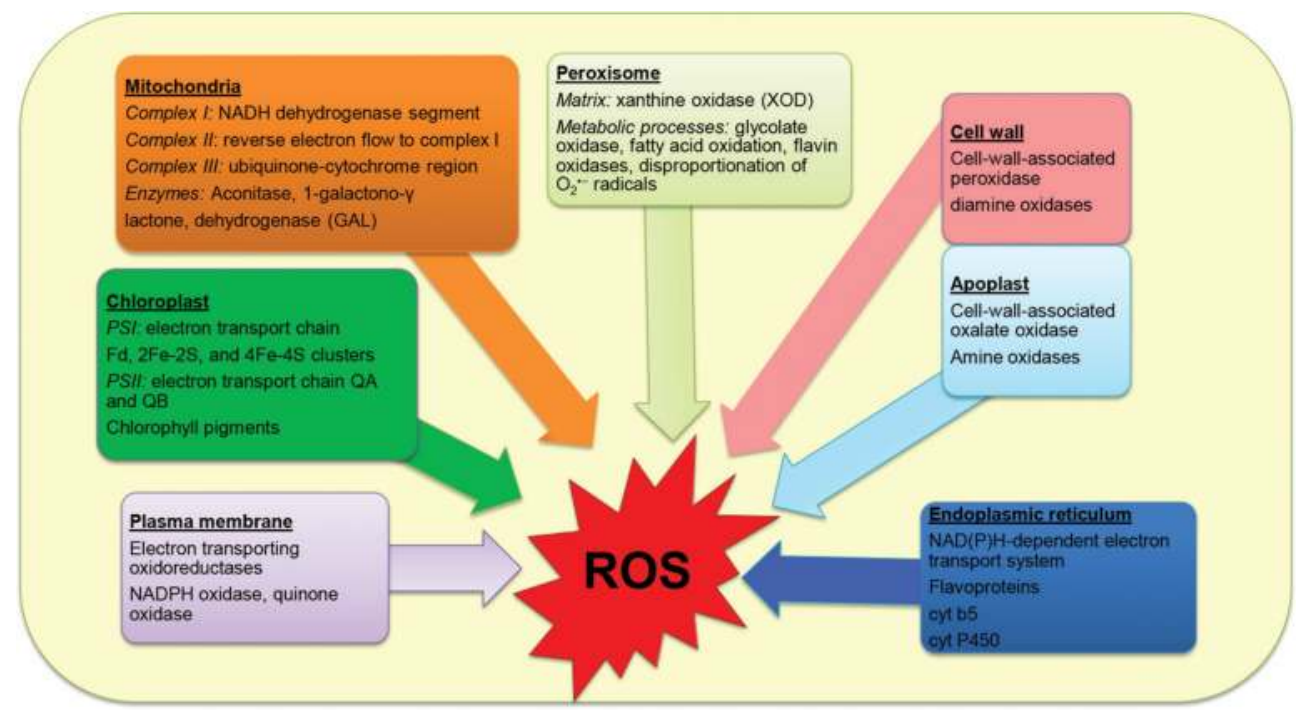

Figure 2. Sites of production of reactive oxygen species (ROS) in plants [63].

Vaidyanathan et al. [66] studied with two rice cultivars, namely salt-sensitive Pusa Basmati 1 (PB) and salt-tolerant Pokkali (PK), and observed that the lipid peroxidation and $\mathrm{H}_{2} \mathrm{O}_{2}$ production were lower in PK than those of $\mathrm{PB}$ with concomitant enhancement of the activities of ROS-detoxifying enzymes as well as elevated levels of AsA and GSH. According to Rahman et al. [17], salt stress ( $150 \mathrm{mM} \mathrm{NaCl})$ increased oxidative damage in time-dependent manner. Lipid peroxidation increased by 80 and $203 \%, \mathrm{H}_{2} \mathrm{O}_{2}$ content by 74 and $92 \%$, and LOX activity increased by 69 and $95 \%$ after 3 and 6 days of treatment, respectively. Accumulation of $\mathrm{H}_{2} \mathrm{O}_{2}$ and $\mathrm{O}_{2}^{-{ }^{--}}$in leaves was much higher than control, especially after 6 days of stress (Figure 3). Results confirmed that the enhanced activities of MDHAR, DHAR, SOD and CAT in salt-stressed rice plant reinforced the salt stress tolerance. Salinity-induced oxidative stress in two rice varieties viz. Swarna (susceptible) and Nonabokra (tolerant) was investigated by Ghosh et al. [67]. The two rice varieties were subjected to $200 \mathrm{mM} \mathrm{NaCl}$, and both varieties showed increased accumulation of ROS and higher lipid peroxidation. Tolerant variety Nonabokra showed reduced damage of biomolecules including lipid, protein, enzymes and membranes with significantly higher accumulation of protective phenolic compounds compared to sensitive variety Swarna. Under high salinity, salt-sensitive varieties, that is, Hitomebore and IR28 showed decreased SOD activity and increased POX activity. The research result of Abdallah et al. [68] suggested that salt stress increased the level of SOD, CAT and Peroxidase (POX) in the shoot of two studied rice varieties, that is, Giza 178 and Giza 177. They found the increased SOD and POX activities in the NaCl-stressed treatment. Hong et al. [69] demonstrated that upon $\mathrm{NaCl}$ exposure, in rice roots, the OsGR2 and OsGR3 isoforms of GR were expressed and triggered by the increased $\mathrm{H}_{2} \mathrm{O}_{2}$ level under salt stress. The two important enzymes those scavenge ROS under salt stress in rice are APX and GR 
[70]. Although the excess generation of ROS under salt stress is very common, it depends on the types of the plant genotype, dose and duration of stress [2]. Tolerant plants show lower ROS generation rate which is correlated with their higher antioxidant defense capacities. In our study with two rice genotypes grown under salt stress (150 and $300 \mathrm{mM} \mathrm{NaCl}$, $48 \mathrm{~h}$ ), we observed that compared with the salt-tolerant variety, the salt-sensitive one showed increased lipid peroxidation (76 and 159\%) and $\mathrm{H}_{2} \mathrm{O}_{2}$ (35 and 69\%) generation at 150 and $300 \mathrm{mM} \mathrm{NaCl}$, respectively [14]. These were due to the increased activities of APX, DHAR, MDHAR, GPX, GR, CAT and glyoxalase I (Gly I) in tolerant (BRRI dhan54) variety than the sensitive variety (BRRI dhan49) [14].
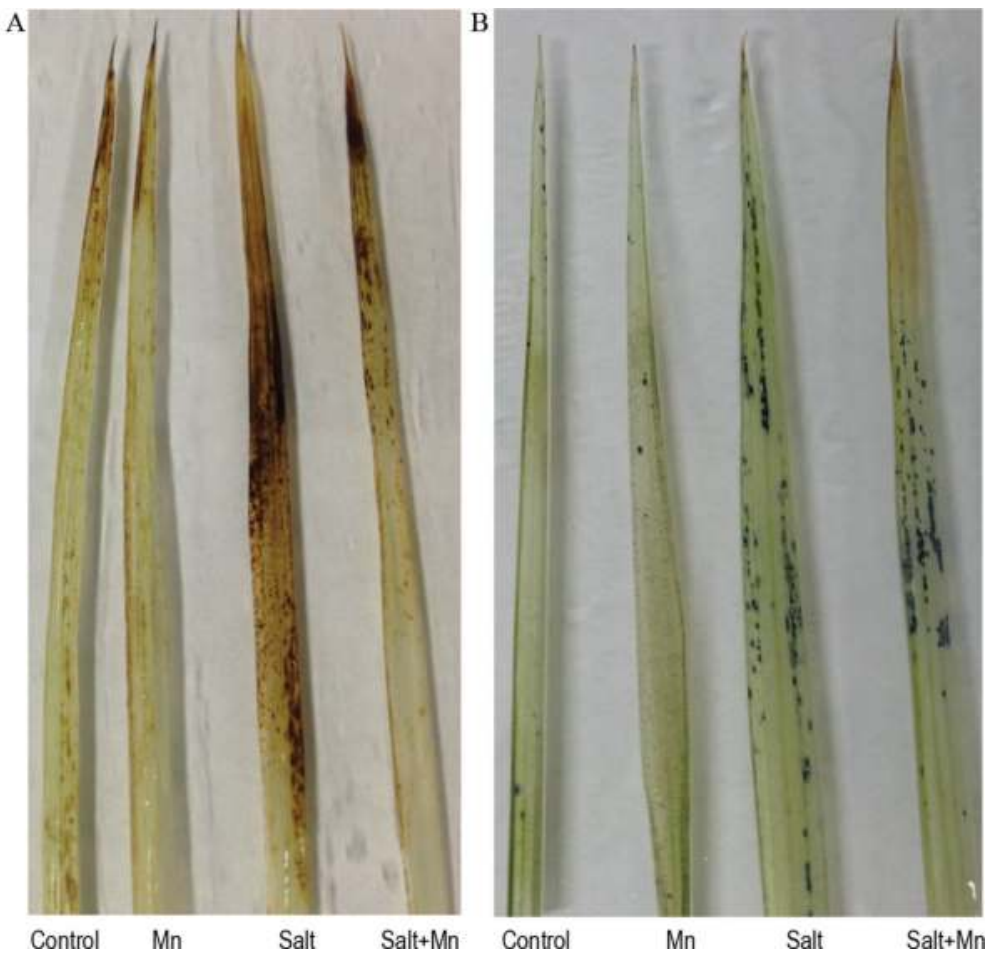

Figure 3. Histochemical localization of $\mathrm{H}_{2} \mathrm{O}_{2}(\mathrm{~A})$ and $\mathrm{O}_{2}{ }^{--}$(B) in leaves of rice seedlings after 6 days of salt stress $(150 \mathrm{mM}$ $\mathrm{NaCl})$ with or without exogenous $\mathrm{Mn}\left(0.5 \mathrm{mM} \mathrm{MnSO}_{4}\right)$. Hydroponically grown 12-day-old seedlings were subjected to both salt and Mn treatments both individually and combinedly (adapted from Rahman et al. [17], with permission from Springer).

\subsection{Yield and grain quality}

Salt-induced damages not only affect the vegetative growth but also affect reproductive development and yield of plant. Yield and grain quality of rice greatly influenced by salinity as salinity hampers growth, photosynthesis and net assimilation rate. Along with the vegetative stages, salt stress affects reproductive stage of rice that reduces yield, yield contributing 
parameters and grain quality. Zheng and Shanon [71] reported that salt stress affected reproductive stage of rice due to lower growth and lower survival percentage of seedlings under different levels of salinity (19-11.7 $\mathrm{dS} \mathrm{m}^{-1}$ ). They noticed that salinity decreased grain yield by decreasing tiller number, pollen viability, fertility percentage and 1000-grain weight where the level of yield reduction increased with increasing the level of salinity. Kumar and Khare [38] subjected tolerant and sensitive cultivar to $100 \mathrm{mM} \mathrm{NaCl}\left(\approx 10 \mathrm{dS} \mathrm{m}^{-1}\right)$ and noted that salinity reduced number of grain per panicle, filled grain percentage, 1000-grain weight and grain yield both in sensitive and in tolerant cultivar where yield reduction was higher in sensitive cultivar. They also noted that grain quality of rice deteriorated by salinity through reduction of protein and starch content of grain. Saleethong et al. [72] reported that salt stress reduced grain yield both in tolerant $(32 \%)$ and in sensitive cultivars $(56 \%)$ by affecting yield contributing parameters where yield reduction is higher in sensitive cultivar. They also reported that salt stress decreased grain quality by reducing $\mathrm{N}, \mathrm{P}, \mathrm{K}$ and $\mathrm{Mg}$ content in rice grain. Ali et al. [73] noticed that salinity $\left(8.5 \mathrm{dS} \mathrm{m}^{-1}\right)$ reduced grain yield of rice by reducing photosynthesis, leaf area index (LAI) and productive tiller. Chunthaburee et al. [74] conducted experiment with four different cultivars and found that salt stress $(25 \mathrm{mM} \mathrm{NaCl})$ reduced yield and harvest index by decreasing 1000-grain weight, filled grain percentage and panicle fertility. Arsa et al. [75] reported that salt stress $(2.5 \% \mathrm{NaCl})$ along with drought stress reduced grain yield and aroma of rice grain. The level of yield reduction increased with increasing the level of salinity. Yield reduction also depends on stages of plant growth when it is affected by salinity. A green house experiment was conducted by Aref [36] with different levels of salinity (2-8 dS $\left.\mathrm{m}^{-1}\right)$ where salt stress exposed at different stages (tillering, panicle initiation, panicle emergence and ripening) of plant. He reported that salinity decreased grain yield, biomass yield and harvest index when salt stress was exposed at tillering and panicle initiation stage and yield reduction increased with increasing the level of salinity.

\section{Use of phytoprotectants in conferring salt stress tolerance in rice}

\subsection{Osmoprotectants}

Plants to cope with salt-induced osmotic stress synthesize and accumulate compatible solutes or osmoprotectants. These are electrically neutral nontoxic and highly soluble molecules. Osmotic balance, stabilization of proteins and membranes are vital functions of osmoprotectants. Plants overexpressing genes for biosynthesis or metabolic genes for osmoprotectants or their precursors showed enhanced salt stress tolerance. Induction of salt stress enhances biosynthesis of osmoprotectants such as Pro, glycine betaine (GB), trehalose (Tre), sorbitol and ectoine, which contribute hyperosmotic stress tolerance generated from salt stress (Table 1) [51, 76]. Several research findings evidenced the role of osmoprotectants to confer salt stress tolerance in rice seedlings (Table 1). Salt stress $(150,200,250$ and $300 \mathrm{mM})$ was imposed to in vitro rice shoot apices cultures of two Malaysian rice cultivars MR 220 and MR 253. Salt stress decreased plant height, root length, biomass and chl content, and these stress effects were alleviated by exogenous Pro application. Supplementation of $5 \mathrm{mM}$ Pro increased endogenous Pro level and plant height of both cultivars. Application of different levels of 
Pro (5, 10, 15 and $20 \mathrm{mM}$ ) increased fresh weight under $150 \mathrm{mM} \mathrm{NaCl}$ stress in both cultivars [77]. Exogenous Pro reduced the $\mathrm{Na}^{+} / \mathrm{K}^{+}$ratio and contributed an improved ionic homeostasis and reduced ion toxicity in salt-affected rice plant [78]. Effect of exogenous Pro (25 and $50 \mathrm{mM}$ ) was studied in salt-sensitive (BRRI dhan29) and moderately salttolerant (BRRI dhan47) cultivars of rice grown under salt stress (50 and $100 \mathrm{mM} \mathrm{NaCl}$ ) condition. Exogenous Pro (either doses) reversed salt-induced growth reduction of both cultivars under $25 \mathrm{mM} \mathrm{NaCl}$ stress. Proline also increased yield of salt-sensitive rice at same salt stress. Exogenous Pro increased chl and endogenous Pro levels and AsA contents. Increasing $\mathrm{K}^{+} / \mathrm{Na}^{+}$ratio exogenous Pro contributes to reduce ionic toxicity. Increasing AsA content and activity of antioxidant enzyme GPX, and Pro imparted oxidative stress tolerance [79]. Improved germination, growth and photosynthetic pigment levels were featured due to Pro (1, 5 and $10 \mathrm{mM})$ supplementation under salt stress $(\mathrm{NaCl} 100,200,300$ and $400 \mathrm{mM}$ ) [80]. Abdallah et al. [68] demonstrated that application of Tre (25 mM) alleviated salt damage effects resulted from 30 and $60 \mathrm{mM} \mathrm{NaCl}$. They observed the beneficial effects on different physiological parameters. Trehalose supplementation with salt stress increased the content of photosynthetic pigments including chl $a$, chl $b$ and carotenoid. Decreasing total carbohydrates exogenous Tre increased total soluble sugar and cellular Tre and decreased Pro level. Trehalose application also modulated antioxidant enzymes such as CAT, SOD and POX activities. Increased fresh weight, dry weight and RWC were also attributed by Tre application under salt stress. Exogenous GB sprays improved water use efficiency, structure of chl, $\mathrm{CO}_{2}$ assimilation and rate of photosynthesis and growth under salt stress condition [42]. Increasing activities of GST and SOD and upregulating the levels of AsA and GSH exogenous Pro ( $5 \mathrm{mM})$ and GB $(5 \mathrm{mM})$ conferred oxidative stress tolerance in both salt-sensitive (BRRI dhan49) and salt-tolerant (BRRI dhan54) rice cultivars where the performance of BRRI dhan54 was better [14]. Nounjan et al. [78] also reported exogenous Tre application-modulated antioxidant enzymes activities including SOD, POX and APX. The increase of Gly II activity by exogenous Pro and GB application is an indication of improving MG toxicity tolerance in salt-affected rice seedlings [14]. Sorbitol (5 and $10 \mathrm{mM}$ ) and Tre (5 and $10 \mathrm{mM}$ ) supplementation improved oxidative stress tolerance of salt (170 mM) stress-affected rice (Oryza sativa L. cv. KDML105) plant by preventing $\mathrm{H}_{2} \mathrm{O}_{2}$ generation, lipid peroxidation and membrane electrolyte leakage [81].

\subsection{Plant hormones}

Plant hormones or phytohormones are chemicals produced within the plants at low concentration and function as signaling molecules those regulate growth of plant. Plant hormones are essential endogenous molecules involved in regulation of plant development and tolerance toward various stresses including salinity [82]. Recently, various kinds of plant hormones such as abscisic acid (ABA), auxin, cytokinins (CK), brassinosteroids, jasmonates and gibberellins $\left(\mathrm{GA}_{3}\right)$ are exogenously applied for alleviating various kind of abiotic stresses including salinity (Table 2). Li et al. [83] reported that ABA pretreatment conferred salt stress tolerance in salt-treated rice seedlings by abundant energy supply and active anabolism of nitrogen, nucleotide acid and carbohydrate through upregulating protein and energy metabolism (Table 1). Seed treatment with ABA played potential role in alleviating salt stress damages by reducing $\mathrm{Na}^{+}$and $\mathrm{Cl}^{-}$concentrations, $\mathrm{Na}^{+} / \mathrm{K}^{+}$ratio and increasing $\mathrm{K}^{+}$and $\mathrm{Ca}^{2+}$ contents [84]. 


\begin{tabular}{|c|c|c|c|c|}
\hline $\begin{array}{l}\text { Species and } \\
\text { cultivars }\end{array}$ & $\begin{array}{l}\text { Salinity dose and } \\
\text { duration }\end{array}$ & Protectants & Protective effects & References \\
\hline O. sativa ssp. indica & $150 \mathrm{mM} \mathrm{NaCl}$ & $50 \mathrm{mM}$ GB & $\begin{array}{l}\text { Increased chl and carotenoid } \\
\text { contents } \\
\text { Increased water use efficiency } \\
\text { (WUE) } \\
\text { Increased seed weight and } \\
\text { yield }\end{array}$ & $\begin{array}{l}\text { Cha-Um and } \\
\text { Kirdmanee [42] }\end{array}$ \\
\hline $\begin{array}{l}\text { O. sativa cv. } \\
\text { Nipponbare }\end{array}$ & $25 \mathrm{mM} \mathrm{NaCl}, 12 \mathrm{~h}$ & $\begin{array}{l}1 \text { and } 5 \mathrm{mM} \text { Pro } \\
\text { and GB }\end{array}$ & $\begin{array}{l}\text { Reduced } \mathrm{Na}^{+} \text {uptake } \\
\text { Increased } \mathrm{K}^{+} / \mathrm{Na}^{+} \text {ratio }\end{array}$ & Sobahan et al. [127] \\
\hline $\begin{array}{l}\text { O. sativa cv. KDML } \\
105\end{array}$ & $100 \mathrm{mM} \mathrm{NaCl}, 6$ days & 10 mM Pro & $\begin{array}{l}\text { Increased } \mathrm{FW} \text { and DW } \\
\text { Reduced } \mathrm{Na}^{+} / \mathrm{K}^{+} \text {ratio } \\
\text { Increased endogenous Pro } \\
\text { and transcript levels of P5CS } \\
\text { and P5CR } \\
\text { Upregulated transcription } \\
\text { of genes encoding several } \\
\text { antioxidant enzymes }\end{array}$ & Nounjan et al. [78] \\
\hline $\begin{array}{l}\text { O. sativa cv. } \\
\text { Nipponbare }\end{array}$ & $150 \mathrm{mM} \mathrm{NaCl}, 5$ days & $5 \mathrm{mM}$ GB & $\begin{array}{l}\text { Prevented salt-induced } \\
\text { swelling of thylakoids, } \\
\text { disintegration of grana } \\
\text { stacking and intergranal } \\
\text { lamellae, and disruption of } \\
\text { mitochondria }\end{array}$ & Rahman et al. [128] \\
\hline $\begin{array}{l}\text { O. sativa cv. KDML } \\
105\end{array}$ & $170 \mathrm{mM} \mathrm{NaCl}, 24 \mathrm{~h}$ & $\begin{array}{l}\text { 5-10 mM Sorbitol } \\
\text { and Tre }\end{array}$ & $\begin{array}{l}\text { Enhanced growth } \\
\text { Reduced } \mathrm{H}_{2} \mathrm{O}_{2} \text { and MDA } \\
\text { contents and electrolyte } \\
\text { leakage }\end{array}$ & $\begin{array}{l}\text { Theerakulpisut and } \\
\text { Gunnula [81] }\end{array}$ \\
\hline $\begin{array}{l}\text { O. sativa L. cv. BRRI } \\
\text { dhan } 29 \text { and BRRI } \\
\text { dhan } 47\end{array}$ & 50 and $100 \mathrm{mM} \mathrm{NaCl}$ & 25 and $50 \mathrm{mM}$ Pro & $\begin{array}{l}\text { Increased } \mathrm{K}^{+} / \mathrm{Na}^{+} \text {ratio } \\
\text { Increased chl, intracellular } \\
\text { Pro } \\
\text { Increased AsA content and } \\
\text { activity of GPX } \\
\text { Increased growth and yield }\end{array}$ & Bhusan et al. [79] \\
\hline $\begin{array}{l}\text { O. sativa cv. Giza } 177 \\
\text { and Giza } 178\end{array}$ & 30 and $60 \mathrm{mM} \mathrm{NaCl}$ & $25 \mathrm{mM}$ Tre & $\begin{array}{l}\text { Increased photosynthetic } \\
\text { pigments and total } \\
\text { carbohydrate } \\
\text { Increased FW, DW and RWC } \\
\text { Decreased total carbohydrates } \\
\text { but increased total soluble } \\
\text { sugar and Tre, decreased Pro } \\
\text { level } \\
\text { Increased CAT activity and } \\
\text { decreased SOD and POX } \\
\text { activities }\end{array}$ & Abdallah et al. [68] \\
\hline
\end{tabular}

Table 1. Beneficial effects of exogenous osmoprotectants in mitigating salt stress-induced damages in rice.

The plant growth regulator auxin, namely indole-3-acetic acid (IAA), plays potential role in improving stress tolerance and grain quality of rice by regulating physiological and biochemical attributes under salt stress condition. Javid et al. [85] reported that exogenous application of IAA improved grain yield of rice by improving 1000-grain weight and filled 
grain percentage through increasing sucrose and glucose content under salt stress condition (Table 1). Seed priming with IAA improves germination percentage by improving $\alpha$-amylase activity (Table 1) [86]. The phytohormone cytokinin, namely kinetin, improves grain yield and grain quality of rice under salt stress condition by improving sucrose and glucose content in rice grain [85].

It is well documented that exogenous brassinosteroids play pivotal role in enhancing salt stress tolerance. Seed priming with 24-epibrassinolide (EBL) improved chl content and stress tolerance by activating antioxidant enzymes SOD, CAT, GPX and DHAR and reducing lipid peroxidation in salt-treated rice seedlings [87]. Exogenous application of EBL and 28-homobrassinolide on salt contaminated growing media $(150 \mathrm{mM} \mathrm{NaCl})$ reverse inhibitory effect of salt stress and improve germination percentage, seedling growth by enhancing levels of nucleic acid and soluble proteins [88]. Jasmonate is involved in plant developmental processes and the defense response by acting as signaling molecule. Kang et al. [89] reported that the exogenous application of jasmonic acid (JA) after 24 and $48 \mathrm{~h}$ of salt stress (20 and $40 \mathrm{mM}$ $\mathrm{NaCl}$ ) exposure recovered salt-induced damages in terms of reduction in root and shoot dry weight, especially in salt-sensitive cultivar compared with tolerant. Exogenously applied JA inhibited salt-induced damage by decreasing Na content and increasing $\mathrm{K}$, $\mathrm{Ca}$ and $\mathrm{Mg}$ levels through upregulating plant hormone such as ABA and JA under salt stress condition. Seed priming with $\mathrm{GA}_{3}$ played positive role in germinating seed and on yield of rice under salt stress condition. Priming with $10 \mu \mathrm{M} \mathrm{GA}_{3}$ improves growth of seedling by increasing starch and total soluble and reducing sugar contents and $\alpha$-amylase activity in germinating seed under salt stress condition [86]. Misratia et al. [90] reported that supplementation with $\mathrm{GA}_{3}$ improved grain yield by increasing panicle plant ${ }^{-1}$, filled grains plant $^{-1}$ and weight of 1000 grains under salt stress condition.

\subsection{Signaling molecule}

Similar to the nervous system of human and other animals, plants also sense different situation through the complex interplay of signal transduction networks and machinery. Accordingly, plants develop behavioral changes or develop cognition and storage of processed information to adapt in rapidly changing or variable environment. In recent years, considerable attempts have been taken to elucidate the signaling network in plants through physiological and molecular approaches. Moreover, exogenous application of some signaling molecules has also established their role in abiotic stress tolerance, and eventfully, these molecules became suitable candidate to be used as exogenous protectants (Table 3). Since last few years, NO has showed multifarious roles in regulating redox-related gene expression, scavenging $\mathrm{O}_{2}{ }^{--}$and terminating chain reaction of lipid oxidation. Therefore, role of $\mathrm{NO}$ in salt stress tolerance in different crop plants is well documented [91, 92]. Habib et al. [93] reported that among different doses of $\mathrm{NO}(0,0.05,0.1,0.2,0.3,0.4$ and $0.5 \mathrm{mM}$ SNP as NO donor $), 0.1$ and $0.2 \mathrm{mM} \mathrm{SNP}$ improved germination under $80 \mathrm{mM}$ salt stress in four rice genotypes. Uchida et al. [94] found that pretreatment with $\mathrm{NO}(1 \mathrm{mM} \mathrm{SNP}, 48 \mathrm{~h})$ upregulated the activity of antioxidant enzymes such as SOD, CAT and APX, and thus, NO alleviated injuries caused by salt stress (100 mM $\mathrm{NaCl}, 8$ days) in rice seedlings. 


\begin{tabular}{|c|c|c|c|c|}
\hline $\begin{array}{l}\text { Species and } \\
\text { cultivars }\end{array}$ & $\begin{array}{l}\text { Salinity dose } \\
\text { and duration }\end{array}$ & Protectants & Protective effects & References \\
\hline O. sativa ssp. Indica & $150 \mathrm{mM} \mathrm{NaCl}, 48 \mathrm{~h}$ & $\begin{array}{l}5 \mu \mathrm{M} \text { ABA } \\
\text { pretreatment, } 48 \mathrm{~h}\end{array}$ & $\begin{array}{l}\text { Upregulated energy } \\
\text { metabolism, primary } \\
\text { metabolism, secondary } \\
\text { metabolism, protein and } \\
\text { defense } \\
\text { Increased FW and decreased } \\
\text { Pro content }\end{array}$ & Li et al. [83] \\
\hline O. sativa cv. IR-26 & $\begin{array}{l}0,50 \text { and } 75 \mathrm{mM} \\
\mathrm{NaCl} \\
\text { Transplanting to } \\
\text { harvest }\end{array}$ & $\begin{array}{l}10 \mu \mathrm{M} \text { ABA priming, } \\
24 \mathrm{~h}\end{array}$ & $\begin{array}{l}\text { Reduced } \mathrm{Na}^{+} \text {and } \mathrm{Cl}^{-} \\
\text {concentrations, } \mathrm{Na}^{+} / \mathrm{K}^{+} \text {ratio } \\
\text { Increased } \mathrm{K}^{+} \text {and } \mathrm{Ca}^{2+} \\
\text { contents } \\
\text { Increased grain yield }\end{array}$ & Gurmani et al. [84] \\
\hline $\begin{array}{l}\text { O. sativa cv. IR 651, } \\
\text { IR29 }\end{array}$ & $\begin{array}{l}6 \mathrm{dS} \mathrm{m}^{-1} \\
\text { Panicle initiation to } \\
\text { harvest }\end{array}$ & $\begin{array}{l}50 \mu \mathrm{M} \text { IAA, foliar } \\
\text { spray }\end{array}$ & $\begin{array}{l}\text { Increased sucrose and glucose } \\
\text { contents } \\
\text { Increased filled grain } \\
\text { percentage, 1000-grain weight } \\
\text { and grain yield }\end{array}$ & Javid et al. [85] \\
\hline $\begin{array}{l}\text { O. sativa cv. } \\
\text { Hwangyoungbyeo }\end{array}$ & $20 \mathrm{mM} \mathrm{NaCl}$ & $\begin{array}{l}20 \mu \mathrm{M} \text { IAA } \\
\text { priming, } 12 \mathrm{~h}\end{array}$ & $\begin{array}{l}\text { Increased } \alpha \text {-amylase activity } \\
\text { Increased germination } \\
\text { percentage }\end{array}$ & Kim et al. [86] \\
\hline $\begin{array}{l}\text { O. sativa cv. IR 651, } \\
\text { IR29 }\end{array}$ & $\begin{array}{l}6 \mathrm{dS} \mathrm{m}^{-1} \\
\text { Panicle initiation to } \\
\text { harvest }\end{array}$ & $\begin{array}{l}50 \mu \mathrm{M} \text { kinetin, foliar } \\
\text { spray }\end{array}$ & $\begin{array}{l}\text { Increased sucrose and glucose } \\
\text { content } \\
\text { Increased filled grain } \\
\text { percentage, 1000-grain weight } \\
\text { and grain yield }\end{array}$ & Javid et al. [85] \\
\hline O. sativa cv. Pokkali & $\begin{array}{l}50 \text { and } 100 \mathrm{mM} \\
\mathrm{NaCl}\end{array}$ & $\begin{array}{l}150 \text { ppm GA foliar } \\
\text { spray }\end{array}$ & $\begin{array}{l}\text { Increased panicle plant }{ }^{-1} \text {, } \\
\text { filled grains plant }{ }^{-1} \text { and } \\
\text { weight of } 1000 \text { grains }^{-} \\
\text {Increased grain yield }\end{array}$ & Misratia et al. [90] \\
\hline $\begin{array}{l}\text { O. sativa cv. Pusa } \\
\text { Basmati-1 }\end{array}$ & $\begin{array}{l}\mathrm{NaCl} 75-125 \mathrm{mM}, \\
12 \text { days }\end{array}$ & $\begin{array}{l}10^{-11}, 10^{-9}, 10^{-7} \mathrm{M} \text { EBL, } \\
\text { priming } 8 \mathrm{~h}\end{array}$ & $\begin{array}{l}\text { Increased chl a, chl b and } \\
\text { total chl content } \\
\text { Decreased MDA content } \\
\text { Upregulated SOD, CAT, GPX } \\
\text { and DHAR activities }\end{array}$ & Sharma et al. [87] \\
\hline O. sativa cv. IR-64 & $\begin{array}{l}150 \mathrm{mM} \mathrm{NaCl} \text {, } \\
7 \text { days }\end{array}$ & $\begin{array}{l}0.5,1 \text { and } \\
3 \mu \mathrm{M} \text { EBL and } \\
\text { 28-homobrassinolide }\end{array}$ & $\begin{array}{l}\text { Increased germination } \\
\text { percentage } \\
\text { Increased seedlings length, } \\
\text { fresh weight and dry weight } \\
\text { Enhanced nucleic acid and } \\
\text { soluble protein level }\end{array}$ & $\begin{array}{l}\text { Anuradha and } \\
\text { Rao [88] }\end{array}$ \\
\hline $\begin{array}{l}\text { O. sativa } \\
\text { cv. } \\
\text { Dongjinchalbyeo } \\
\text { and Dongjinbyeo }\end{array}$ & $\begin{array}{l}20,40 \text { and } 80 \mathrm{mM} \\
\mathrm{NaCl}, 8 \text { days }\end{array}$ & $30 \mu \mathrm{M} J \mathrm{~A}$ & $\begin{array}{l}\text { Decreased } \mathrm{Na} \text { content } \\
\text { Increased } \mathrm{K}, \mathrm{Ca} \text { and } \mathrm{Mg} \\
\text { contents } \\
\text { Increased JA and ABA } \\
\text { contents } \\
\text { Increased quantum yield of } \\
\text { PS II }\end{array}$ & Kang et al. [89] \\
\hline
\end{tabular}

Table 2. Beneficial effects of exogenous photohormones in mitigating salt stress-induced damages in rice. 


\begin{tabular}{|c|c|c|c|c|}
\hline Species and cultivars & $\begin{array}{l}\text { Salinity dose and } \\
\text { duration }\end{array}$ & Protectants & Protective effects & References \\
\hline O. sativa cv. IRRI-6 & $80 \mathrm{mM} \mathrm{NaCl}$ & 0.1 mM SNP, spray & $\begin{array}{l}\text { - Improved growth and } \\
\text { biomass production } \\
\text { - Increased Pro } \\
\text { - Enhanced the activities of } \\
\text { antioxidant enzymes } \\
\text { - Increased yield }\end{array}$ & $\begin{array}{l}\text { Habib and } \\
\text { Ashraf [98] }\end{array}$ \\
\hline $\begin{array}{l}\text { O. sativa cv. Shaheen, } \\
\text { PB-95, IRRI-6 and } \\
\text { KS-282 }\end{array}$ & $80 \mathrm{mM} \mathrm{NaCl}$ & $\begin{array}{l}\text { Seed soaking with } \\
0.05-0.5 \mathrm{mM} \text { SNP }\end{array}$ & $\begin{array}{l}\text { - Improved seed germination } \\
\text { - Enhanced seedling growth } \\
\text { and vigority }\end{array}$ & Habib et al. [93] \\
\hline $\begin{array}{l}\text { O. sativa cv. } \\
\text { Nipponbare }\end{array}$ & $100 \mathrm{mM} \mathrm{NaCl}, 8$ days & $\begin{array}{l}\mathrm{H}_{2} \mathrm{O}_{2}(<10 \mu \mathrm{M}), \\
\text { pretreatment, } 48 \mathrm{~h}\end{array}$ & $\begin{array}{l}\text { Enhanced the activities of } \\
\text { ROS scavenging enzymes }\end{array}$ & Uchida et al. [93] \\
\hline $\begin{array}{l}\text { O. sativa cv. Pokkali } \\
\text { and KDML } 105\end{array}$ & $25 \mathrm{mM} \mathrm{NaCl}$ & $1 \mathrm{mM} \mathrm{Spd}$ & $\begin{array}{l}\text { Increased fresh weight, dry } \\
\text { weight and grain yield }\end{array}$ & $\begin{array}{l}\text { Paweena et al. } \\
{[110]}\end{array}$ \\
\hline $\begin{array}{l}\text { O. sativa cv. Pokkali } \\
\text { and KDML } 105\end{array}$ & $150 \mathrm{mM} \mathrm{NaCl}, 7$ days & $1 \mathrm{mM} \mathrm{Spd}$ & $\begin{array}{l}\text { Increased Plant height, } \\
\text { fresh and dry weight } \\
\text { - Scavenging free radicals } \\
\text { Spd stabilized membrane, } \\
\text { and maintained } \mathrm{K}^{+} / \mathrm{Na}^{+} \\
\text {status }\end{array}$ & $\begin{array}{l}\text { Saleethong et al. } \\
\text { [109] }\end{array}$ \\
\hline $\begin{array}{l}\text { O. sativa cv. } \\
\text { Nonabokra and } \\
\text { Swarna }\end{array}$ & $200 \mathrm{mM} \mathrm{NaCl}, 7$ days & 1 and $2 \mathrm{mM}$ Put & $\begin{array}{l}\text { - Decreased } \mathrm{O}_{2}^{\cdot-} \text { and } \mathrm{H}_{2} \mathrm{O}_{2} \\
\text { contents } \\
\text { - Increased anthocyanin and } \\
\text { flavonoid contents, CAT, } \\
\text { GPX and GR activities }\end{array}$ & Ghosh et al. [67] \\
\hline $\begin{array}{l}\text { O. sativa cv. IKP and } \\
\text { Pokkali }\end{array}$ & $\begin{array}{l}50 \text { and } 100 \mathrm{mM} \\
\mathrm{NaCl}, 5 \text { and } 12 \text { days }\end{array}$ & $1 \mathrm{mM}$ Put & 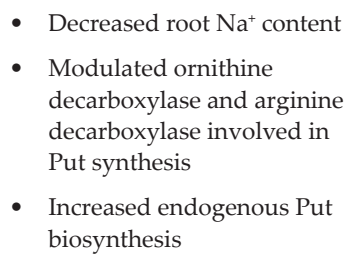 & $\begin{array}{l}\text { Quinet et al. } \\
\text { [108] }\end{array}$ \\
\hline $\begin{array}{l}\text { O. sativa M-1-48 and } \\
\text { Pokkali }\end{array}$ & $150 \mathrm{mM} \mathrm{NaCl}, 6 \mathrm{~h}$ & $1 \mathrm{mM}$ Spd or Spm & $\begin{array}{l}\text { - Prevented chl loss } \\
\text { - Improved photosystem } \\
\text { activity } \\
\text { - Decreased } \mathrm{Na}^{+} \text {content, and } \\
\text { increased } \mathrm{K}^{+}, \mathrm{Ca}^{2+} \text { and } \mathrm{Mg}^{2+} \\
\text { contents }\end{array}$ & $\begin{array}{l}\text { Chattopadhayay } \\
\text { et al. [107] }\end{array}$ \\
\hline $\begin{array}{l}\text { O. sativa cv. I Kong } \\
\text { Pao }\end{array}$ & 150 and $300 \mathrm{mM}$ & $\begin{array}{l}1 \text { and } 10 \mathrm{mM} \text { Put, } \\
\text { Spd and Spm }\end{array}$ & 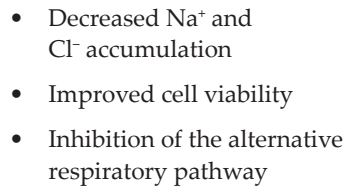 & $\begin{array}{l}\text { Ndayiragije and } \\
\text { Lutts [106] }\end{array}$ \\
\hline $\begin{array}{l}\text { O. sativa cv. I Kong } \\
\text { Pao }\end{array}$ & $\begin{array}{l}50 \text { or } 100 \mathrm{mM} \mathrm{NaCl} \text {, } \\
5,12 \text { and } 19 \text { days }\end{array}$ & $\begin{array}{l}1 \mathrm{mM} \text { Put, Spd and } \\
\text { Spm }\end{array}$ & $\begin{array}{l}\text { - Increased } \mathrm{K}^{+} / \mathrm{Na}^{+} \text {ratio in } \\
\text { the shoots }\end{array}$ & $\begin{array}{l}\text { Ndayiragije and } \\
\text { Lutts [106] }\end{array}$ \\
\hline
\end{tabular}




\begin{tabular}{|c|c|c|c|c|}
\hline Species and cultivars & $\begin{array}{l}\text { Salinity dose and } \\
\text { duration }\end{array}$ & Protectants & Protective effects & References \\
\hline $\begin{array}{l}\text { O. sativa cv. M-1-48, } \\
\text { Nonabokra and } \\
\text { Gobindobhog }\end{array}$ & $200 \mathrm{mM} \mathrm{NaCl}$ & $\begin{array}{l}1 \mathrm{mM} \text { Spd or } 1 \mathrm{mM} \\
\text { Spm }\end{array}$ & $\begin{array}{l}\text { - } \begin{array}{l}\text { Alleviation of growth } \\
\text { inhibition, cellular damages }\end{array} \\
\text { Decrease of } \mathrm{H}_{2} \mathrm{O}_{2^{\prime}} \mathrm{MDA} \text {, } \\
\text { LOX activity, protein } \\
\text { oxidation and protease } \\
\text { activity } \\
\text { - Maintenance of } \mathrm{K}^{+} / \mathrm{Na}^{+} \\
\text {balance, modulation osmo- } \\
\text { lytes and improvement } \\
\text { of activity of antioxidant } \\
\text { enzymes }\end{array}$ & $\begin{array}{l}\text { Roychoudhury } \\
\text { et al. [112] }\end{array}$ \\
\hline $\begin{array}{l}\text { O. sativa cv. Niewdam } \\
\text { Gs. no. } 00621 \text { and } \\
\text { KKU-LLR-039 }\end{array}$ & $\begin{array}{l}150 \mathrm{mM} \mathrm{NaCl} \text {, } \\
10 \text { days }\end{array}$ & $1 \mathrm{mM}$ Spd & $\begin{array}{l}\text { - Improved growth, anthocy- } \\
\text { anin and chl contents } \\
\text { Decreased } \mathrm{Na}+/ \mathrm{K}^{+} \text {ratio, } \\
\text { Pro and } \mathrm{H}_{2} \mathrm{O}_{2} \text { contents, } \\
\text { particularly in the sensitive } \\
\text { cultivar }\end{array}$ & $\begin{array}{l}\text { Chunthaburee } \\
\text { et al. [111] }\end{array}$ \\
\hline $\begin{array}{l}\text { Oryza sativa cv. IKP } \\
\text { and Pokkali }\end{array}$ & $\begin{array}{l}50 \text { and } 100 \mathrm{mM} \\
\mathrm{NaCl}, 5 \text { days }\end{array}$ & $1 \mathrm{mM}$ Put, 5 days & $\begin{array}{l}\text { - } \text { Reduced } \mathrm{Na}^{+} \text {accumulation } \\
\text { - Increased PA content }\end{array}$ & $\begin{array}{l}\text { Quinet et al. } \\
\text { [108] }\end{array}$ \\
\hline $\begin{array}{l}\text { O. sativa cv. Pokkali } \\
\text { and KDML105 }\end{array}$ & $150 \mathrm{mM} \mathrm{NaCl}, 7$ days & $1 \mathrm{mM} \mathrm{Spd}, 24 \mathrm{~h}$ & $\begin{array}{l}\text { - Improved growth } \\
\text { - Increased membrane } \\
\text { stabilization } \\
\text { - Efficient scavenging of free } \\
\text { radicals and decreased } \\
\text { MDA } \\
\text { - Maintained } \mathrm{K}^{+} / \mathrm{Na}^{+} \text {status }\end{array}$ & $\begin{array}{l}\text { Saleethong et al. } \\
\text { [109] }\end{array}$ \\
\hline $\begin{array}{l}\text { O. sativa cv. M-1-48, } \\
\text { Nonabokra and } \\
\text { Gobindobhog }\end{array}$ & $\begin{array}{l}200 \mathrm{mM} \mathrm{NaCl} \text {, } \\
15 \text { days }\end{array}$ & $\begin{array}{l}1 \mathrm{mM} \text { Spd or } 1 \mathrm{mM} \\
\text { Spm, } 15 \text { days }\end{array}$ & $\begin{array}{l}\text { - Increased } \mathrm{Chl} \text { content } \\
\text { - } \text { Decreased } \mathrm{Na}^{+} \text {content } \\
\text { - } \text { Decreased } \mathrm{MDA} \text { and } \mathrm{H}_{2} \mathrm{O}_{2} \\
\text { levels } \\
\text { - Increased antioxidant } \\
\text { metabolism }\end{array}$ & $\begin{array}{l}\text { Roychoudhury } \\
\text { et al. [112] }\end{array}$ \\
\hline
\end{tabular}

Table 3. Beneficial effects of exogenous signaling molecules and polyamines in mitigating salt stress-induced damages in rice.

Unlike $\mathrm{NO}, \mathrm{H}_{2} \mathrm{O}_{2}$ is a long-lasting $\mathrm{ROS}$, is able to cross organelle membrane and thus contributes to regulate redox-related gene expression. Depending on concentration, $\mathrm{H}_{2} \mathrm{O}_{2}$ itself causes damages to cell at higher concentration like other ROS or alleviates damaging effect of different abiotic stresses including salt stress at low concentration in various crop plants $[2,95]$. However, triggering programmed cell death (PCD) during biotic stress is a well-known fact regulated by $\mathrm{H}_{2} \mathrm{O}_{2}$ signaling [96]. Use of $\mathrm{H}_{2} \mathrm{O}_{2}$ (at low concentration) as protectant has been well studied under salt stress. Uchida et al. [94] found that exogenous application of $\mathrm{H}_{2} \mathrm{O}_{2}$ upregulated activities of antioxidant defense enzymes (CAT, SOD, POX, APX 
and GR), and thus, $\mathrm{H}_{2} \mathrm{O}_{2}$ mitigated salt-induced damages in rice. In another study, Wang et al. [97] investigated potential role of $\mathrm{H}_{2} \mathrm{O}_{2}$ in salt stress tolerance in two rice varieties (Zhenghan-2 and Yujing-6). Exogenous $\mathrm{H}_{2} \mathrm{O}_{2}$ enhanced APX, CAT, peroxidases (POD), SOD and G6PDH activities in roots of both rice cultivars in a dose-dependent manner. Using a plasma membrane (PM), NADPH oxidase inhibitor, diphenyleneiodonium (DPI) and NaCl-induced $\mathrm{H}_{2} \mathrm{O}_{2}$ accumulation were reduced, and therefore, the activity of above enzymes was downregulated. They concluded that PM NADPH oxidase-mediated reduction of $\mathrm{H}_{2} \mathrm{O}_{2}$ is responsible for salt stress tolerance in Zhenghan-2 variety of rice by modulating the cellular antioxidant level. In a recent study, Habib and Ashraf [98] found that exogenous nitric oxide donor (0.1 and $0.2 \mathrm{mM} \mathrm{SNP})$ could enhance salt $(80 \mathrm{mM} \mathrm{NaCl})$ stress tolerance in rice by enhancing the activities of antioxidant enzymes (SOD, POD and CAT). However, the effect was dose dependent where $0.1 \mathrm{mM}$ SNP was found to be more effective. They studied four different cultivars and found variable amount of decrease in growth and biomass production which was associated with increase in Pro, AsA, $\mathrm{H}_{2} \mathrm{O}_{2}$ and MDA contents. However, spraying with NO donor effectively upregulated the antioxidant defense and improved growth and grain yield [98].

\subsection{Polyamines}

Polyamines (PAs) are organic cations distributing in broad range of organism perform a range of physiological functions [99]. Modulation of PAs interacting with other biomolecules (hormones/signaling molecule/amino acids) plays pivotal roles during plant developmental and stress adaptation process. PAs being cations bind to negatively charged surfaces of membrane and biomolecules and protect those from damage [100]. PAs stimulate antioxidant system which reduces ROS production and oxidative damages to plants [51, 101]. PAs have some direct action under salt stress which alleviates salt-induced damage in plants. As polycation, PAs can block a variety of cation through different pathways like $\mathrm{K}^{+}$-selective channels, vacuolar-type channels and ammonium channels [102]. Salt-induced $\mathrm{Na}^{+}$influx, $\mathrm{K}^{+}$efflux, shoot-to-root $\mathrm{K}^{+}$recirculation and disruption of $\mathrm{K}^{+} / \mathrm{Na}^{+}$homeostasis are directly modulated by PAs due to cationic nature which have been reported as obvious positive effects of PAs under salt stress [51, 103, 104]. Some previously reported roles of PAs in rice plant under salt stress condition have been discussed here (Table 3 ).

Ndayiragije and Lutts [105] reported that $1 \mathrm{mM}$ Put, Spd or Spm application increased $\mathrm{K}^{+} / \mathrm{Na}^{+}$ ratio in the shoots of salt-sensitive Oryza sativa L. cv. I Kong Pao. In their further study, they reported that exogenous Put, Spd or Spm $(1$ and $10 \mathrm{mM})$ application decreased $\mathrm{Na}^{+}$and $\mathrm{Cl}^{-}$accumulation, improved cell viability and inhibited the alternative respiratory pathway in salt-sensitive Oryza sativa L. cv. I Kong Pao [106]. Chattopadhayay et al. [107] described the roles of exogenous PAs to improve cation anion balance and photosynthesis. Exogenous Spd and Spm supplementation prevented salt-induced chl loss, inhibition of photochemical reactions of photosynthesis, improved PS I and PS II activities. Spd and Spm supplementation also decreased leakage of electrolytes and amino acids from roots and shoots caused by salinity. Exogenous Spd and Spm on endogenous decreased $\mathrm{Na}^{+}$content and increased $\mathrm{K}^{+}, \mathrm{Ca}^{2+}$ and $\mathrm{Mg}^{2+}$ contents in salt-affected rice seedlings. Exogenous PAs were more effective to improve the performance of salt-sensitive M-1-48 plants, compared to tolerant Pokkali [107]. Exogenous Put (1 mM) 
addition increased endogenous Put level in both cultivars under salt stress. Exogenous Putinduced endogenous PAs metabolism was correlated with improved performance of rice cultivars under salt stress. Salt stress modulated the activities of PAs biosynthesis enzymes. Activities of ornithine decarboxylase and arginine decarboxylase (involved in Put synthesis) were higher in salt-treated plants and after exogenous Put addition in salt-resistant Pokkali than in salt-sensitive IKP cultivars of rice. Exogenous Put reduced $\mathrm{Na}^{+}$content in root of IKP cultivar [108]. Spermidine pretreatment $\left(1 \mathrm{mM} \mathrm{Spd}, 24 \mathrm{~h}\right.$ ) improved $\mathrm{K}^{+} / \mathrm{Na}^{+}$homeostasis in salt-tolerant (Pokkali) and salt-sensitive (KDML 105) rice cultivars in exposure with salt stress (150 $\mathrm{mM} \mathrm{NaCl}, 7$ days). Increased chl content and improved plant height, fresh and dry weight of both cultivars were confirmed by Spd pretreatment under salt stress [109]. Ghosh et al. [67] demonstrated that exogenous Put ( 1 and $2 \mathrm{mM})$ improved antioxidant defense system that reduced oxidative stress in salt-affected rice seedlings. Salt stress $(200 \mathrm{mM} \mathrm{NaCl})$ increased generation of $\mathrm{O}_{2}{ }^{--}, \mathrm{H}_{2} \mathrm{O}_{2}$ in tissues and caused membrane lipid peroxidation and protein carbonylation. Exogenous Put application increased the contents of nonenzymatic antioxidants such as anthocyanin and flavonoid. Activities of antioxidant enzymes GPX, CAT and GR were enhanced by exogenous Put application. Thus, enhanced antioxidant system conferred oxidative stress tolerance and overall salt stress tolerance in rice [67]. Two cultivars of rice differing in their salt tolerance capacity [Pokkali (salt-tolerant) and KDML 105 (salt-sensitive)] were examined to evaluate their performance after Spd pretreatment. Spermidine pretreatment decreased $\mathrm{H}_{2} \mathrm{O}_{2}$ accumulation. Exogenous Spd pretreatment also prevented lipid peroxidation and decreased electrolyte leakage by stabilizing membrane. Prevention of chl breakdown was also demonstrated in Spd pretreated salt-affected rice seedlings. These results indicated the roles of exogenous Spd to improve oxidative stress tolerance under salt stress [109]. Paweena et al. [110] noted the roles of Spd to improve yield attributes which ultimately increased the yield of salt-affected rice cultivars. Pretreatment with Spd increased grain yield per plant of KDML 105 by $62 \%$ and that of Pokkali by $16 \%$ under salt stress $(25 \mathrm{mM} \mathrm{NaCl})$ condition. Seed priming with Spd improved growth, anthocyanin and chl contents and decreased $\mathrm{Na}^{+} / \mathrm{K}^{+}$ratio, Pro and $\mathrm{H}_{2} \mathrm{O}_{2}$ contents, particularly in the sensitive cultivar [111]. Alleviation of growth inhibition, cellular damages, decrease of $\mathrm{H}_{2} \mathrm{O}_{2}$, MDA, LOX activity, protein oxidation and protease activity, maintenance of $\mathrm{K}^{+} / \mathrm{Na}^{+}$balance, modulation of osmolytes and improvement of activity of antioxidant enzymes (GPX, APX and CAT) were attributed by exogenous Spd and Spm supplementation those conferred salt stress tolerance in different rice cultivars. However, among different rice cultivars [(M-1-48 (salt-sensitive), Nonabokra (salt-tolerant) and Gobindobhog (highly sensitive)], salt-sensitive rice cultivars responded better compared to salt-tolerant cultivars in response to exogenous PAs application under salt stress [112].

\subsection{Trace elements}

The effect of trace elements in mitigating the effect of abiotic stress in plants including salinity has become a matter of interest in recent decades. However, the mechanism is still unclear, and their responses are mostly dose dependent $[3,113]$. In recent decades, plenty of researches have been carried on the positive effect of trace element on salt stress tolerance in rice (Table 4), while many of them are focused on silicon (Si) as rice is a Si accumulator and its essentiality is well documented in rice. 


\begin{tabular}{|c|c|c|c|c|}
\hline $\begin{array}{l}\text { Species and } \\
\text { cultivars }\end{array}$ & $\begin{array}{l}\text { Salinity dose } \\
\text { and duration }\end{array}$ & Protectants & Protective effects & References \\
\hline $\begin{array}{l}\text { O. sativa cv. BRRI } \\
\text { dhan } 47\end{array}$ & $\begin{array}{l}150 \mathrm{mM} \mathrm{NaCl}, 3 \\
\text { and } 6 \text { days }\end{array}$ & $\begin{array}{l}0.5 \mathrm{mM} \mathrm{MnSO}_{4^{\prime}} \\
3 \text { and } 6 \text { days }\end{array}$ & $\begin{array}{l}\text { Decreased } \mathrm{Na}^{+} \text {uptake and the } \\
\mathrm{Na}^{+} / \mathrm{K}^{+} \text {ratio, and increased } \mathrm{K}^{+} \\
\text {uptake } \\
\text { - Increased the content of phe- } \\
\text { nolic compounds, flavonoids } \\
\text { and AsA } \\
\text { - Increased RWC and decreased } \\
\text { osmotic potential and Pro } \\
\text { content } \\
\text { Decreased ROS production, } \\
\text { lipid peroxidation and LOX } \\
\text { activity } \\
\text { Increased the activities of } \\
\text { MDHAR, DHAR, SOD, CAT, } \\
\text { Gly I and Gly II }\end{array}$ & Rahman et al. [17] \\
\hline $\begin{array}{l}\text { O. sativa } \mathrm{cv} \text {. } \\
\text { Khazar and } \\
\text { Zayandehrood }\end{array}$ & $100 \mathrm{mM} \mathrm{NaCl}$ & $\begin{array}{l}3 \mathrm{mMSi} \text { as } \\
\mathrm{Na}_{2} \mathrm{SiO}_{3}\end{array}$ & $\begin{array}{l}\text { Decreased } \mathrm{Na}^{+} \text {and } \mathrm{K}^{+} \text {con- } \\
\text { centrations and increased } \mathrm{Si} \\
\text { concentration } \\
\text { - Increased } \mathrm{Fv} / \mathrm{Fm} \text { ratio }\end{array}$ & Mahdieh et al. [119] \\
\hline O. sativa cv. IR29 & $10 \mathrm{dS} \mathrm{m}^{-1}$ & $\begin{array}{l}150 \mathrm{mg} \mathrm{kg}^{-1} \\
\mathrm{Na}_{2} \mathrm{SiO}_{3}\end{array}$ & $\begin{array}{l}\text { - Increased FW and DW of shoot } \\
\text { - Increased photosynthesis rate } \\
\text { - Increased activities of APX } \\
\text { and GPX and decreased CAT } \\
\text { activity } \\
\text { - Decreased } \mathrm{Na}^{+} \text {content }\end{array}$ & Farooq et al. [117] \\
\hline $\begin{array}{l}\text { O. sativa cv. KS-282 } \\
\text { and IRRI-6 }\end{array}$ & $10 \mathrm{dS} \mathrm{m}^{-1}$ & $\begin{array}{l}150 \mathrm{mg} \mathrm{kg}^{-1} \\
\mathrm{Na}_{2} \mathrm{SiO}_{3}\end{array}$ & $\begin{array}{l}\text { Increased APX and GPX activi- } \\
\text { ties and decreased CAT activity } \\
\text { - Reduced } \mathrm{Na}^{+} \text {uptake and tran- } \\
\text { spiration rate } \\
\text { - Increased RWC and photosyn- } \\
\text { thetic efficiency }\end{array}$ & Farooq et al. [117] \\
\hline $\begin{array}{l}\text { O. sativa cv. } \\
\text { Dongjin }\end{array}$ & $\begin{array}{l}100 \mathrm{mM} \mathrm{NaCl} ; 6 \text {, } \\
12 \text { and } 24 \mathrm{~h}\end{array}$ & $\begin{array}{l}0.5,1 \text { and } \\
2 \mathrm{mM} \\
\mathrm{Na}_{2} \mathrm{SiO}_{3} 5 \mathrm{H}_{2} \mathrm{O} ; \\
6,12 \text { and } 24 \mathrm{~h}\end{array}$ & $\begin{array}{l}\text { - Increased shoot length, Shoot } \\
\text { fresh weight and chl content } \\
\text { - Decreased electrolytic leakage } \\
\text { and } \mathrm{Na}^{+} \text {uptake }\end{array}$ & Kim et al. [129] \\
\hline $\begin{array}{l}\text { O. sativa cv. GR4, } \\
\text { CSR } 10 \text { and IR36 }\end{array}$ & $50 \mathrm{mM} \mathrm{NaCl}$ & $3 \mathrm{mM} \mathrm{Na}_{2} \mathrm{SiO}_{3}$ & $\begin{array}{l}\text { Increased root and shoot dry } \\
\text { weight } \\
\text { Decreased concentrations of } \mathrm{Cl}^{-} \text {, } \\
\mathrm{Na}^{+} \text {and } \mathrm{K}^{+} \text {and increased } \mathrm{K}^{+} / \mathrm{Cl}^{-} \\
\text {and } \mathrm{K}^{+} \mathrm{Na}^{+} \text {ratio } \\
\text { - Increased net assimilation } \\
\text { rate, stomatal conductance, } \\
\text { intercellular } \mathrm{CO}_{2} \text { and decreased } \\
\text { transpiration rate }\end{array}$ & Shi et al. [130] \\
\hline
\end{tabular}




\begin{tabular}{|c|c|c|c|c|}
\hline $\begin{array}{l}\text { Species and } \\
\text { cultivars }\end{array}$ & $\begin{array}{l}\text { Salinity dose } \\
\text { and duration }\end{array}$ & Protectants & Protective effects & References \\
\hline $\begin{array}{l}\text { O. sativa cv. } \\
\text { Pokkali and Peta }\end{array}$ & $\begin{array}{l}200 \mathrm{mM} \mathrm{NaCl}, \\
6-8 \text { days }\end{array}$ & $\begin{array}{l}0.065 \text { mM GSH, } \\
6-8 \text { days }\end{array}$ & $\begin{array}{l}\text { - Decreased } \mathrm{H}_{2} \mathrm{O}_{2} \text { and MDA } \\
\text { contents } \\
\text { - Increased the activities of SOD, } \\
\text { APX and GR } \\
\text { - Increased levels of endogenous } \\
\text { AsA and GSH }\end{array}$ & Wang et al. [122] \\
\hline O. sativa cv. MRQ74 & $\begin{array}{l}200 \text { mM NaCl, } \\
3 \text { months }\end{array}$ & $\begin{array}{l}0.5 \text { mM AsA, } \\
3 \text { months }\end{array}$ & $\begin{array}{l}\text { Decreased } \mathrm{Na}^{+} \text {uptake and the } \\
\mathrm{Na}^{+} / \mathrm{K}^{+} \text {ratio; increased } \mathrm{K}^{+} \text {and } \\
\mathrm{Ca}^{2+} \text { uptake } \\
\text { - Increased RGR, fresh mass and } \\
\text { dry mass } \\
\text { - Increased Pro content } \\
\text { - Increased POD, CAT and SOD }\end{array}$ & Alhasnawi et al. [123] \\
\hline $\begin{array}{l}\text { O.sativa cv. } \\
\text { MRQ74 and MR269 }\end{array}$ & $\begin{array}{l}200 \mathrm{mM} \mathrm{NaCl}, \\
14 \text { days }\end{array}$ & $\begin{array}{l}1.0 \text { mM AsA, } \\
14 \text { days }\end{array}$ & $\begin{array}{l}\text { Decreased } \mathrm{Na}^{+} \text {uptake and the } \\
\mathrm{Na}^{+} / \mathrm{K}^{+} \text {ratio; increased } \mathrm{N} \text { and } \\
\mathrm{K}^{+} \text {uptake } \\
\text { - Increased length, FW, DW of } \\
\text { shoot and root } \\
\text { - Increased chl content }\end{array}$ & Alhasnawi et al. [124] \\
\hline $\begin{array}{l}\text { O. sativa cv. } \\
\text { Ciherang, IR } \\
64, \text { Lambur, } \\
\text { Banyuasin, IR } \\
\text { 42, Inpara 10, } \\
\text { Margasari }\end{array}$ & $\begin{array}{l}5.99 \mathrm{dS} \mathrm{m}^{-1}(\mathrm{EC}) \\
\text { whole life cycle }\end{array}$ & $\begin{array}{l}1500 \text { ppm AsA, } \\
\text { applied in } 4 \\
\text { times for whole } \\
\text { life cycle }\end{array}$ & $\begin{array}{l}\text { - Increased plant height and leaf } \\
\text { area } \\
\text { - Increased number of produc- } \\
\text { tive tiller } \\
\text { - Increased length of panicle }\end{array}$ & Barus et al. [125] \\
\hline $\begin{array}{l}\text { O. sativa cv. } \\
\text { Pokkali and Peta }\end{array}$ & $\begin{array}{l}200 \mathrm{mM} \mathrm{NaCl}, \\
6-8 \text { days }\end{array}$ & $\begin{array}{l}5 \text { mM AsA, } \\
6-8 \text { days }\end{array}$ & $\begin{array}{l}\text { - Decreased } \mathrm{H}_{2} \mathrm{O}_{2} \text { and MDA } \\
\text { contents } \\
\text { - Increased the activities of SOD, } \\
\text { APX and GR } \\
\text { - Increased levels of endogenous } \\
\text { AsA and GSH }\end{array}$ & Wang et al. [122] \\
\hline O. sativa cv. Pokkali & $\begin{array}{l}120 \mathrm{mM} \mathrm{NaCl}, \\
72 \mathrm{~h}\end{array}$ & $\begin{array}{l}0.75 \text { and } \\
1.5 \mathrm{mM} \text { gallic } \\
\text { acid (phenolic } \\
\text { compounds), } \\
72 \mathrm{~h}\end{array}$ & $\begin{array}{l}\text { - Significantly decreased } \mathrm{H}_{2} \mathrm{O}_{2} \\
\text { and TBARS contents } \\
\text { - Enhanced the activities of SOD, } \\
\text { CAT, POX and APX } \\
\text { - Increased of RGR, osmotic } \\
\text { potential ( } \Psi \Pi), \mathrm{Fv} / \mathrm{Fm} \text { and Pro }\end{array}$ & $\begin{array}{l}\text { Ozfidan-Konakci et } \\
\text { al. [126] }\end{array}$ \\
\hline
\end{tabular}

Table 4. Beneficial effects of exogenous trace elements and antioxidants in mitigating salt stress-induced damages in rice.

Zinc (Zn)-supplemented rice plants showed enhanced salt tolerance as reported by Iqbal and Aslam [114]. In their study, both salt-sensitive and salt-tolerant genotypes showed less plant height tiller, dry weight and fresh weight under salinity $(70 \mathrm{mM} \mathrm{NaCl})$, while these 
effects were reversed by the application of Zn (1-1000 nM). However, the effect of Zn was dose dependent. Mehmood et al. [115] observed that boron (B) could ameliorate the negative effect of salt stress in rice grown in the saline and saline sodic soils $\left(9 \mathrm{dS} \mathrm{m}^{-1}\right)$. However, the effect was mostly dose dependent. Boron fertilized at $1.5 \mathrm{~kg} \mathrm{~B} \mathrm{ha}^{-1}$ showed higher yield of rice which was due to reduced shoot $\mathrm{Na}^{+}$and $\mathrm{Cl}^{-}$concentration and better ratio of $\mathrm{K}^{+}$and $\mathrm{Na}^{+}$in shoot. However, B application at $6 \mathrm{~kg} \mathrm{~B} \mathrm{ha}^{-1}$ showed adverse affect on grain and straw production in saline sodic soils. Boron supplementation also improved seed setting of rice [115]. Zayed et al. [116] studied the effect of manganese (Mn), $\mathrm{Zn}$ and iron (Fe) on the performance of rice in saline soil. They observed that the application of the all micronutrients either alone or combined improved rice growth, dry matter production, leaf area index and chl content under saline condition. Moreover, yield attributes like panicle numbers, panicle weight, filled grains panicle ${ }^{-1}$ and 1000 -grain weight were markedly increased when plants received the micronutrient which resulted in higher yield under saline soil [116]. Farooq et al. [117] investigated the beneficial effects of exogenous Si in rice grown under salinity. Both salt-sensitive (IRRI-6) and salt-tolerant (KS-282) cultivars were used in this study. Their study showed that salt stress $\left(10 \mathrm{dS} \mathrm{m}^{-1}\right)$ reduced plant biomass by damaging the membrane and reducing special products analysis division values and photosynthetic efficiency which was accompanied by higher accumulation of $\mathrm{Na}^{+}$and lower $\mathrm{K}^{+}$. However, the damages were higher in IRRI-6 than KS-282. Importantly, Si (150 mg kg-1) application counteracted the adverse effects of salt stress by reducing the uptake $\mathrm{Na}^{+}$, lowering transpiration rate and improving water content and photosynthetic efficiency [117]. They also found the Si-induced upregulation of the activities of antioxidant enzymes viz. APX, GPX and CAT, and thus, the oxidative stress was mitigated [118]. Mahdieh et al. [119] investigated the relative performance of Si-supplemented salt-sensitive and salt-tolerant rice cultivars (25-day-old) under saline condition (100 mM NaCl, $96 \mathrm{~h}$ ). Investigation revealed that both rice cultivars showed stunted growth, reduced photosynthetic efficiency (Fv/Fm) and increased chlorosis which were associated with increased $\mathrm{Na}^{+}$accumulation. On the other hand, Si supplementation decreased shoot $\mathrm{Na}^{+}$concentration, but increased Si uptake which in turn increased the growth, chl content and Fv/Fm ratio in salt-treated plants. In our laboratory, we studied the protective effect of exogenous $\mathrm{Mn}\left(0.5 \mathrm{mM} \mathrm{MnSO}_{4}\right)$ in mitigating short-term salt stress (150 mM NaCl, 3 and 6 days) in rice seedlings cv. BRRI dhan47. Any level of salinity not only diminished the ion homeostasis due to $\mathrm{Na}^{+}$influx and $\mathrm{K}^{+}$efflux but also caused osmotic stress due to limited amount of water and increased compatible solute content. As a result, salt-treated seedlings showed inhibited growth, chlorosis and excess generation of ROS $\left(\mathrm{H}_{2} \mathrm{O}_{2}\right.$ and $\left.\mathrm{O}_{2}{ }^{--}\right)$and higher amount of lipid peroxidation which was due to the disruption of antioxidant defense system [17]. However, the seedlings supplemented with exogenous Mn showed significant recovery of growth and chlorosis (Figure 4) by improving ionic and osmotic homeostasis through decreasing $\mathrm{Na}^{+}$influx and increasing water status, respectively. Exogenous Mn also enhanced the activities of antioxidant enzymes (MDHAR, DHAR, SOD and CAT) and maintained higher level of nonenzymatic antioxidants (AsA and GSH) which were able to detoxify ROS. Exogenous Mn also upregulated the glyoxalase system and detoxified the level of toxic MG. Moreover, exogenous Mn effectively maintained the ion homeostasis and improved the growth of seedlings under salinity. The beneficial role of Se in mitigating salt stress has been studied in many plants but hardly found in rice. Recently, we completed a pot experiment with three rice varieties viz. BRRI dhan45, BRRI dhan47 
and Nipponbare grown under different concentration of saltwater (50-150 mM). Salt stresses reduced the plant height and tillers hill ${ }^{-1}$, leaf relative water content and chl content in dosedependent manner. Salt stress also reduced the effective tillers hill ${ }^{-1}$, number of filled grains panicle $^{-1}, 1000$-grain weight, grain yield and straw yield. However, when the plants were supplemented with $0.5 \mathrm{mM}$ Se (sodium selenite, $\mathrm{Na}_{2} \mathrm{SeO}_{3}$ ), these observed parameters were significantly increased compared to salt treatment alone. Importantly, the beneficial effect of Se on salt stress tolerance was prominent up to $100 \mathrm{mM} \mathrm{NaCl}$, while it could not be more beneficial above this level of salt concentration [120]. The response of rice plant to Se and salt stress greatly varied in different cultivars (Figure 5).
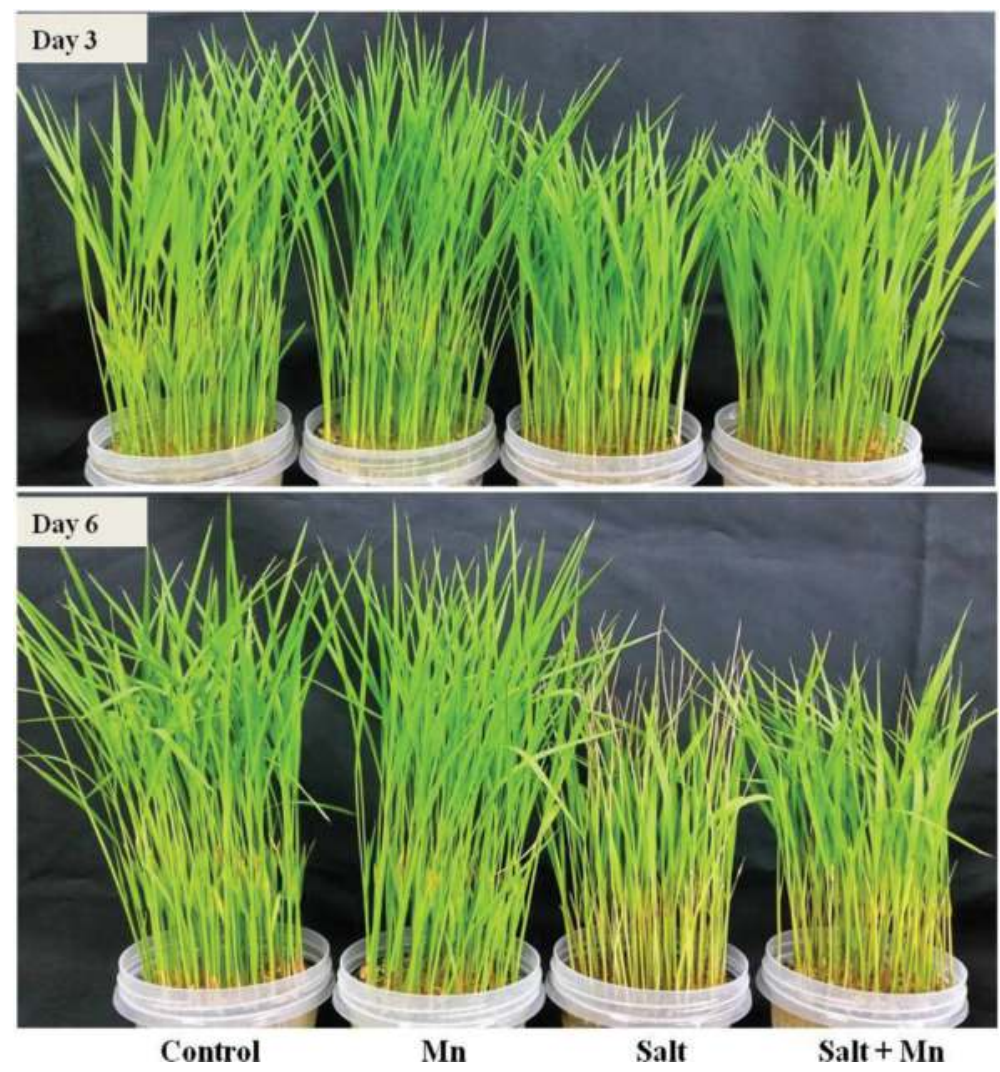

Figure 4. Phenotypic appearance of rice seedlings under salt stress with and without exogenous Mn. Here, Mn and salt indicate $0.5 \mathrm{mM} \mathrm{MnSO}_{4}$ and $150 \mathrm{mM} \mathrm{NaCl}$, respectively (adapted from Rahman et al. [17], with permission from Springer).

\subsection{Antioxidants}

Mitigation of abiotic stresses including salinity by using antioxidants as exogenous protectants is becoming familiar for plant biologists in recent time. There are many antioxidants including AsA, GSH, tocopherol, nonprotein amino acid, phenolic compounds and alkaloids 
that play a significant role in mitigation of excessive cellular reactive oxygen species activities caused by salt stresses $[2,121]$. Moreover, these protectants have diverse roles in plant growth and development. Several research results have indicated that exogenous application of antioxidants provided significant protection against salt-induced damages in plants [3]. However, very few researches have been carried out on the positive effect of antioxidant under salt stress in rice plant (Table 4).

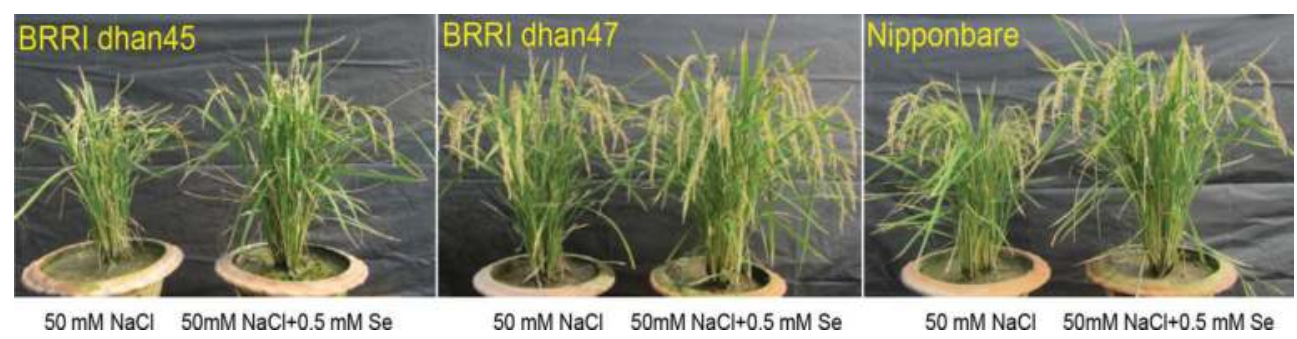

Figure 5. Effect of Se supplementation in mitigating adverse effects of salt stress in different rice cultivars. Plants were subjected to $50 \mathrm{mM} \mathrm{NaCl}$ throughout its life cycles with or without $0.5 \mathrm{mM} \mathrm{Na}_{2} \mathrm{SeO}_{3}$.

Wang et al. [122] carried out an experiment to identify the effects of exogenous AsA and GSH on two rice cultivars, the salt-tolerant cultivar Pokkali and the salt-sensitive cultivar Peta, under salt stress $(200 \mathrm{mM} \mathrm{NaCl})$. They found that salt stress hampered the antioxidant enzyme activities and increased MDA and $\mathrm{H}_{2} \mathrm{O}_{2}$ contents of the chloroplasts. But, addition of exogenous AsA and GSH reduced $\mathrm{H}_{2} \mathrm{O}_{2}$ and MDA contents and increased SOD, APX, GR activities and endogenous levels of AsA and GSH in the chloroplasts of both cultivars under salt stress, but the effects were significantly more prominent in cv. Pokkali. On the other hand, GSH played more significant role than the AsA on the plastidial reactive oxygen scavenging systems. These results indicated that exogenous AsA and GSH differentially increased salinity tolerance and mitigate the damages of salt-induced stress. Alhasnawi et al. [123] investigated the effect of exogenous AsA application on embryogenic callus of indica rice $\mathrm{cv}$. MRQ74 cultured under saline conditions $(200 \mathrm{mM} \mathrm{NaCl})$. They reported that salt stress reduced relative growth rate (RGR), callus fresh and dry masses, $\mathrm{K}^{+}$and $\mathrm{Ca}^{+2}$ content, and increased $\mathrm{Na}^{+}$content and $\mathrm{Na}^{+} / \mathrm{K}^{+}$ratio. Application of AsA $(0.5 \mathrm{mM})$ alleviated these effects of salinity. The activities of SOD, CAT and POX, as well as content of Pro, were increased due to $\mathrm{NaCl}$ treatment, and these parameters were mostly further increased by AsA application. Accordingly, AsA was able to enhance callus tolerance to $\mathrm{NaCl}$ stress. Similarly, AsA lessened the damaging effect of salt stress in two rice cultivars (MRQ74 and MR269) under $\mathrm{NaCl}$ stress [124]. They demonstrated that AsA (1.0 mM) considerably influenced a number of metabolic processes, leading to enhanced ability for seedling survival and growth through balancing or changing in the $\mathrm{Na}^{+}$and $\mathrm{K}^{+}$levels as well as the intracellular level of AsA. Exogenous AsA had effects on $\mathrm{Na}^{+}$and $\mathrm{K}^{+}$uptake and improving chl which have vital roles in number of metabolic processes. Ascorbic acid decreased $\mathrm{Na}^{+}$uptake and the $\mathrm{Na}^{+} / \mathrm{K}^{+}$ratio and increased the uptake of $\mathrm{Na}^{+}$and $\mathrm{K}^{+}$in contrast to salt stress alone. It also increased the length, FW and DW of shoot and root and chl content. Therefore, it may 
be concluded that exogenous application of AsA has low external osmotic potential and ion toxicity and might be effective in mitigating the effects of salt stress. Barus et al. [125] studied the effect of salt stress and its interaction with AsA on some morphological traits of eight varieties of rice (Ciherang, IR 64, Lambur, Batanghari, Banyuasin, IR 42, Inpara 10 and Margasari). AsA (0, 500, 1000 and 1500 ppm) was applied in four times at the age of 15, 35,55 and 75 days after sowing. All concentrations of ascorbic acid generally had a positive effect on morphological characters. The leaf area, productive tiller and panicle length increased in all cultivars after application of AsA. However, the best response was found at $1500 \mathrm{ppm}$ concentration of AsA on Banyuasin variety. Besides the AsA and GSH, gallic acid (GA) had a remarkable biological effect on plants growth, including an improvement in plants' tolerance under salinity stress conditions. Ozfidan-Konakci et al. [126] conducted a study to examine the effect of exogenously applied GA on the tolerance of two rice cultivars (tolerant cultivar Pokkali and sensitive cultivar IR-28) to salt $(\mathrm{NaCl})$ stress. Salt stress reduced the maximum photochemical efficiency $(\mathrm{Fv} / \mathrm{Fm})$ ratio, photochemical quenching coefficient (qP) and actual quantum yield (ФPSII) of two rice cultivars, but the effect was more distinct in IR-28. Also, a significant increase in $\mathrm{H}_{2} \mathrm{O}_{2}$ content and lipid peroxidation was observed in $\mathrm{NaCl}$ treatment. The salt stress sensitivity of plants was higher in IR-28 than in Pokkali. However, addition of GA in NaCl-stressed Pokkali rice markedly decreased $\mathrm{H}_{2} \mathrm{O}_{2}$ and thiobarbituric acid reactive substances (TBARS) contents, and enhanced the activities of SOD, CAT, APX and POX as well as increase of relative growth rate (RGR), osmotic potential $(\Psi \Pi), \mathrm{Fv} / \mathrm{Fm}$ ratio and Pro level in comparison with salt stress alone. So, it can be said that $\mathrm{GA}$ is able to mitigate $\mathrm{NaCl}$ toxicity of rice plant by increasing the level of antioxidants activities and photosynthetic efficiency.

\section{Conclusion and perspectives}

Salinity is one of the major abiotic stresses and constraints for agriculture worldwide because most of the crop plants are sensitive to salt stress [131]. Salt stress adversely affects physiology and biochemistry of plants primarily by creating water stress, ionic imbalance and toxicity, nutritional disorders, alteration of metabolic processes, oxidative stress, membrane disorganization and reduction of cell division and expansion. However, plants have well-organized antioxidative defense mechanisms at the cellular level to minimize the toxicity. But in severe stress condition plant cannot cope with stress by its own mechanism. So, use of exogenous protectants like osmoprotectants, plant hormones, signaling molecules, polyamines, trace elements, antioxidants, etc., are now popular in research aimed at enhancing abiotic stress tolerance. On the other hand, rice is one of the world's most important cereal crops with exceptional agricultural and economic importance as being a staple food for more than $50 \%$ population worldwide. This crop is highly susceptible to salt stress, and the productivity of rice decreased to a great extent under salinity. In recent time, the biochemical responses of rice plants to salt stress have been studied intensively. The use of exogenous protectants in rice plant under salt stress condition has been found to be very much effective to mitigate salt-induced damages. The mechanisms by which protectants regulate activities of enzymes are enhanced and are undoubtedly interesting and demand insightful studies in rice plant. 
The clear mechanism of defense and signal transduction pathways is still in dark and should be discovered. Furthermore, the exact dose, duration and proper methods of application of exogenous protectants in rice plant under salt condition should be studied more precisely for complete elucidation of mechanism of protection.

\section{Author details}

Anisur Rahman, Kamrun Nahar ${ }^{1,3}$, Jubayer Al Mahmud ${ }^{1,4}$, Mirza Hasanuzzaman², Md. Shahadat Hossain, and Masayuki Fujita ${ }^{1 *}$

*Address all correspondence to: fujita@ag.kagawa-u.ac.jp

1 Laboratory of Plant Stress Responses, Department of Applied Biological Science, Faculty of Agriculture, Kagawa University, Miki-cho, Japan

2 Department of Agronomy, Faculty of Agriculture, Sher-e-Bangla Agricultural University, Dhaka, Bangladesh

3 Department of Agricultural Botany, Faculty of Agriculture, Sher-e-Bangla Agricultural University, Dhaka, Bangladesh

4 Department of Agroforestry and Environmental Science, Faculty of Agriculture, Sher-eBangla Agricultural University, Dhaka, Bangladesh

\section{References}

[1] Cramer GR, Urano K, Delort S, Pezzotti M, Shinozaki K. Effects of abiotic stress on plants: a systems biology perspective. BMC Plant Biology 2011; 11:163. doi:10.1186/ 1471-2229-11-163

[2] Hasanuzzaman M, Hossain MA, da Silva JAT, Fujita M. Plant responses and tolerance to abiotic oxidative stress: antioxidant defense is a key factor. In: Bandi V, Shanker AK, Shanker C, Mandapaka M (eds) Crop stress and its management: perspectives and strategies. Berlin: Springer; 2012. pp. 261-316.

[3] Hasanuzzaman M, Nahar K, Fujita M. Plant response to salt stress and role of exogenous protectants to mitigate salt-induced damages. In: Ahmad P, Azooz MM, Prasad MNV (eds) Ecophysiology and responses of plants under salt stress. New York: Springer; 2013. pp. 25-87.

[4] Hasanuzzaman M, Nahar K, Fujita M, Ahmad P, Chandna R, Prasad MNV, Ozturk M. Enhancing plant productivity under salt stress: relevance of poly-omics. In: Ahmad P, Azooz MM, Prasad MNV (eds) Salt stress in plants: signaling, omics and adaptations. New York: Springer; 2013. pp. 113-156.

[5] Munns R, Tester M. Mechanism of salinity tolerance. Annual Review of Plant Biology 2008; 59:651-681. 
[6] Mahajan S, Tuteja N. Cold, salinity and drought stresses: an overview. Archives of Biochemistry and Biophysics 2005; 444:139-158.

[7] Tester M, Davenport R. $\mathrm{Na}^{+}$tolerance in higher plants. Annals of Botany 2003; 91: 503-507.

[8] Hasanuzzaman M, Fujita M, Islam MN, Ahamed KU, Nahar K. Performance of four irrigated rice varieties under different levels of salinity stress. International Journal of Integrative Biology 2009; 6:85-90.

[9] Hasanuzzaman M, Hossain MA, Fujita M. Nitric oxide modulates antioxidant defense and the methylglyoxal detoxification system and reduces salinity-induced damage of wheat seedlings. Plant Biotechnology Reports 2011; 5:353-365.

[10] Hasanuzzaman M, Hossain MA, Fujita M. Selenium-induced up-regulation of the antioxidant defense and methylglyoxal detoxification system reduces salinity-induced damage in rapeseed seedlings. Biological Trace Element Research 2011; 143:1704-1721.

[11] Wu GQ, Wang SM. Calcium regulates $\mathrm{K}^{+} / \mathrm{Na}^{+}$homeostasis in rice (Oryza sativa L.) under saline conditions. Plant, Soil and Environment 2012; 58:121-127.

[12] Mishra P, Bhoomika K, Dubey RS. Differential responses of antioxidative defense system to prolonged salinity stress in salt-tolerant and salt-sensitive Indica rice (Oryza sativa L.) seedlings. Protoplasma 2013; 250:3-19.

[13] Peng K, Chunling L, Wuxin Y, Chunlan L, Xiangdong L, Shen Z. Manganese uptake and interactions with cadmium in the hyperaccumulator-Phytolacca americana L. Journal of Hazardous Materials 2008; 154:674-681.

[14] Hasanuzzaman M, Alam MM, Rahman A, Hasanuzzaman M, Nahar K, Fujita M. Exogenous proline and glycine betaine mediated upregulation of antioxidant defense and glyoxalase systems provides better protection against salt-induced oxidative stress in two rice (Oryza sativa L.) varieties. BioMed Research International 2014. doi:10.1155/2014/757219

[15] Khush, G. What it will take to feed 5.0 billion rice consumers in 2030. Plant Molecular Biology 2005; 59:1-6. doi:10.1007/s11103-005-2159-2155

[16] Munns R. Comparative physiology of salt and water stress. Plant Cell and Environment 2002; 25:239-250.

[17] Rahman A, Hossain MS, Mahmud J, Nahar K, Hasanuzzaman M, Fujita M. Manganeseinduced salt stress tolerance in rice seedlings: regulation of ion homeostasis, antioxidant defense and glyoxalase systems. Physiology and Molecular Biology of Plants 2016. doi:10.1007/s12298-016-0371-1

[18] Rahman A, Nahar K, Hasanuzzaman M, Fujita M. Calcium supplementation improves $\mathrm{Na}^{+} / \mathrm{K}^{+}$ratio, antioxidant defense and glyoxalase systems in salt-stressed rice seedlings. Frontiers in Plant Science 2016. doi:10.3389/fpls.2016.00609

[19] Lee KS, Choi WY, Ko JC, Kim TS, Gregoria GB. Salinity tolerance of japonica and indica rice (Oryza sativa L.) at the seedling stage. Planta 2003; 216:1043-1046. 
[20] Todaka D, Nakashima K, Shinozaki K, Yamaguchi-Shinozaki K. Towards understanding transcriptional regulatory networks in abiotic stress responses and tolerance in rice. Rice 2012; 5:1-9.

[21] Das P, Nutan KK, Singla-Pareek SN, Pareek A. Understanding salinity responses and adopting 'omics-based' approaches to generate salinity tolerant cultivars of rice. Frontiers in Plant Scince 2015. doi:10.3389/fpls.2015.007

[22] IRRI. Stress and disease tolerance. In: Rice Knowledge bank. International Rice Research Institute, Manila, Philippines (2006). Available from: http://www.knowledgebank.irri. org/ricebreedingcourse/Breeding_for_salt_tolerance.htm

[23] Xiong L, Zhu JK. Molecular and genetic aspects of plant responses to osmotic stress. Plant, Cell and Environment 2002; 25: 131-139.

[24] Horie T, Karahara I, Katsuhara M. Salinity tolerance mechanisms in glycophytes: an overview with the central focus on rice plants. Rice 2012; 5:11. doi:10.1186/1939-8433-5-11

[25] Wahid A, Farooq M, Basra SMA, Rasul E, Siddique KHM. Germination of seeds and propagules under salt stress. In: Pessarakli M (ed) Handbook of plant and crop stress. Boca Raton: CRC Press; 2011, pp. 321-337.

[26] Hua-long L, Han-jing S, Jing-guo W, Yang L, De-tang Z, Hong-wei Z. Effect of seed soaking with exogenous proline on seed germination of rice under salt stress. Journal of Northeast Agricultural University 2014; 21(3):1-6.

[27] Özdemir F, Bor M, Demiral T, Türkan I. Effects of 24-epibrassinolide on seed germination, seedling growth, lipid peroxidation, proline content and antioxidative system of rice (Oryza sativa L.) under salinity. Plant Growth Regulation 2014; 42: 203-211.

[28] Hakim MA, Juraimi AS, Begum M, Hanafi MM, Ismail MR, Selamat A. Effect of salt stress on germination and early seedling growth of rice (Oryza sativa L.). African Journal of Biotechnology 2010; 9:1911-1918.

[29] Rajakumar R. A study on effect of salt stress in the seed germination and biochemical parameters of rice (Oryza sativa 1.) under in vitro condition. Asian Journal of Plant Science and Research 2013; 3:20-25.

[30] Shereen A, Ansari R, Raza S, Mumtaz S, Khan MA, Ali Khan M. Salinity induced metabolic changes in rice (oryza sativa 1.) seeds during germination. Pakistan Journal of Botany 2011; 43:1659-1661.

[31] Islam MM, Karim MA. Evaluation of rice (Oryza sativa L.) genotypes at germination and early seedling stage for their tolerance to salinity. The Agriculturists 2010; 8(2): 57-65.

[32] Abbas MK, Ali AS, Hasan HH, Ghal RH. Salt tolerance study of six cultivars of rice (Oryza sativa L.) during germination and early seedling growth. Journal of Agricultural Scince 2013. doi:10.5539/jas.v5n1p250 
[33] Kazemi K, Eskandari H. Effects of salt stress on germination and early seedling growth of rice (Oryza sativa) cultivars in Iran. African Journal of Biotechnology 2011; 10(77): 17789-17792.

[34] Ologundudu AF, Adelusi AA, Akinwale RO. Effect of salt stress on germination and growth parameters of rice (Oryza sativa L.). Notulae Scientia Biologicae 2014; 6(2): 237-243.

[35] Makihara D, Tsuda M, Morita M, Hirai Y, Kurod T. Effect of salinity on the growth and development of rice (Oryza sativa L.) varieties. Japanese Journal of Tropical Agriculture 1999; 43(4):285-294.

[36] Aref F. Effect of saline irrigation water on yield and yield components of rice (Oryza sativa L.). African Journal of Biotechnology 2013; 12:3503-3513.

[37] Hasegawa P, Bressan RA, Zhu JK, Bohnert HJ. Plant cellular and molecular responses to high salinity. Annual Review of Plant Physiology and Plant Molecular Biology 2000; 51:463-499.

[38] Kumar V, Khare T. Differential growth and yield responses of salt-tolerant and susceptible rice cultivars to individual $\left(\mathrm{Na}^{+}\right.$and $\left.\mathrm{Cl}^{-}\right)$and additive stress effects of $\mathrm{NaCl}$. Acta Physiologiae Plantarum 2016; 38:170. doi:10.1007/s11738-016-2191-x

[39] Chaves MM, Flexas J, Pinheiro C. Photosynthesis underdrought and salt stress: regulation mechanisms from wholeplant to cell. Annals of Botany 2009; 103:551-560.

[40] Ashraf M, Harris PJC. Photosynthesis under stressful environments: an overview. Photosynthetica 2013; 5:163-190.

[41] Moradi F, Abdelbagi M, Ismail. Responses of photosynthesis, chlorophyll fluorescence and ROS-scavenging systems to salt stress during seedling and reproductive stages in rice. Annals of Botany 2007; 99: 1161-1173.

[42] Cha-Um S, Kirdmanee C. Effect of glycinebetaine on proline, water use, and photosynthetic efficiencies, and growth of rice seedlings under salt stress. Turkish Journal of Agriculture and Forestry 2010; 34:517-527.

[43] Amirjani MR. Effect of $\mathrm{NaCl}$ on some physiological parameters of rice. European Journal of Biological Sciences 2010; 3:06-16.

[44] Pattanagul W, Thitisaksakul M. Effect of salinity stress on growth and carbohydrate metabolism in three rice (Oryza sativa L.) cultivars differing in salinity tolerance. Indian Journal of Experimental Biology 2008; 46:736-742.

[45] Sohan D, Jason R, Zajcek J. Plant-water relations of $\mathrm{NaCl}$ and calcium-treated treated sunflower plants. Environmental and Experimental Botany 1999; 42:105-111.

[46] Romero-Aranda R, Soria T, Cuartero S. Tomato plant-water uptake and plant-water relationships under saline growth conditions. Plant Science 2001; 160:265-272. 
[47] Lutts S, Kinet JM, Bouharmont J. Effects of salt stress on growth, mineral nutrition and proline accumulation in relation to osmotic adjustment in rice (Oryza sativa L.) cultivars differing in salinity resistance. Plant Growth Regulation 1996; 19:201-218.

[48] Redillas MCFR, Park SH, Lee JW, Kim YC, Jeong JS, Jung H, Bang SW, Hahn TR, Kim JK. Accumulation of trehalose increases soluble sugar contents in rice plants conferring tolerance to drought and salt stress. Plant Biotechnology Reports 2012; 6:89-96.

[49] Nemati I, Moradi F, Gholizadeh S, Esmaeili MA, Bihamta MR. The effect of salinity stress on ions and soluble sugars distribution in leaves, leaf sheaths and roots of rice (Oryza sativa L.) seedlings. Plant Soil Environment 2011; 57(1): 26-33.

[50] Boriboonkaset T, Theerawitaya C, Pichakum A, Cha-um S, Takabe T, Kirdmanee C. Expression levels of some starch metabolism related genes in flag leaf of two contrasting rice genotypes exposed to salt stress. Australian Journal of Crop Science 2012; 6:1579-1586.

[51] Gill SS, Tuteja N. Polyamines and abiotic stress tolerance in plants. Plant Signaling \& Behavior 2010; 51:26-33.

[52] Summart J, Thanonkeo P, Panichajakul S, Prathepha P, McManus MT. Effect of salt stress on growth, inorganic ion and proline accumulation in Thai aromatic rice, Khao Dawk. Mali 105, callus culture. African Journal of Biotechnology 2010; 9:145-152.

[53] Parida AK, Das AB. Salt tolerance and salinity effects on plants: a review. Ecotoxicology and Environmental Safety 2010; 60:324-349.

[54] Sumithra K, Jutur PP, Carmel BD, Reddy AR. Salinity-induced changes in two cultivars of Vigna radiata: responses of antioxidative and proline metabolism. Plant Growth Regulation 2006; 50:11-22.

[55] Shabala S, Demidchick V, Shabala L, Cuin TA, Smith SJ, Miller AJ, Davies JM, Newman IA. Extracellular $\mathrm{Ca}^{2+}$ ameliorates $\mathrm{NaCl}$-induced $\mathrm{K}^{+}$loss from Arabidopsis root and leaf cells by controlling plasmamembrane $\mathrm{K}^{+}$-permeable channels. Plant Physiology 2006; 141:1653-1665.

[56] Wang H, Zhang M, Guo R, Shi D, Liu B, Lin X, Yang C. Effects of salt stress on ion balance and nitrogen metabolism of old and young leaves in rice (Oryza sativa L.). BMC Plant Biology 2012; 12:194.

[57] Carillo P, Annunziata MG, Pontecorvo G, Fuggi A, Woodrow P. Salinity stress and salt tolerance. In: Shanker A (ed) Abiotic stress in plants-mechanisms and adaptations. Crotia: InTech; 2011, pp. 2-35.

[58] Zhu ZJ, Wei GQ, Li J, Qian QQ, Yu JQ. Silicon alleviates salt stress and increases antioxidant enzymes activity in leaves of salt-stressed cucumber (Cucumis sativus L.). Plant Science 2004; 167:527-533.

[59] Zhang Z, Liu Q, Song H, Rong X, Ismail AM. Responses of contrasting rice (Oryza sativa L.) genotypes to salt stress as affected by nutrient concentrations. Agricultural Sciences in China 2011; 10:195-206. 
[60] Azarin KV, Alabushev AV, Usatov AV, Kostylev PI, Kolokolova NS, Usatova OA. Effects of salt stress on ion balance at vegetative stage in rice (Oryza sativa L.). Online Journal of Biological Sciences 2016; 16:76-81.

[61] Ahmad P, Umar S. Oxidative stress: role of antioxidants in plants. New Delhi: Studium Press; 2011.

[62] Bose J, Rodrigo-Moreno A, Shabala S. ROS homeostasis in halophyte s in the context of salinity stress tolerance. Journal of Experimental Botany 2014; 65:1241-1257.

[63] Hasanuzzaman M, Nahar K, Fujita M. Extreme temperatures, oxidative stress and antioxidant defense in plants. In: Vahdati K, Leslie C (eds) Abiotic stress-plant responses and applications in agriculture. Rijeka: InTech; 2013. pp. 169-205. doi:10.5772/54833

[64] Hernandez JA, Jimenez A, Mullineaux P, Sevilla F. Tolerance of pea (Pisum sativum L.) to longterm salt stress is associated with induction of antioxidant defences. Plant Cell and Environment 2000; 23(8):853-862.

[65] Tanou G, Molassiotis A, Diamantidis G. Induction of reactive oxygen species and necrotic death-like destruction in strawberry leaves by salinity. Environmental and Experimental Botany 2009; 65:270-281.

[66] Vaidyanathan H, Sivakumar P, Chakrabarty R, Thomas G. Scavenging of reactive oxygen species in $\mathrm{NaCl}$-stressed rice (Oryza sativa L.)-differential response in salt-tolerant and sensitive varieties. Biologia Plantarum 2003; 165:1411-1418.

[67] Ghosh N, Das SP, Mandal C, Gupta S, Das K, Dey N, Adak MK. Variations of antioxidative responses in two rice cultivars with polyamine treatment under salinity stress. Physiology and Molecular Biology of Plants 2012; 18:301-313.

[68] Abdallah MMS, Abdelgawad ZA, El-Bassiouny HMS. Alleviation of the adverse effects of salinity stress using trehalose in two rice varieties. South African Journal of Botany 2016; 103:275-282.

[69] Hong C, Chao Y, Yang M, Cheng S, Cho S, Kao C. NaCl-induced expression of glutathione reductase in roots of rice (Oryza sativa L.) seedlings is mediated through hydrogen peroxide but not abscisic acid. Plant and Soil 2009; 320:103-115.

[70] Halliwell B, Gutteridge MJC. Free radicals in biology and medicine, 4th edn. London: Oxford University Press; 2007.

[71] Zeng L, Shannon MC. Salinity effects on seedling growth and yield components of rice. Crop Science 2000; 40:996-1003.

[72] Saleethong P, Sanitchon J, Kong-ngern K, Theerakulpisut P. Effects of exogenous spermidine (Spd) on yield, yield-related parameters and mineral composition of rice (Oryza sativa L. ssp. indica) grains under salt stress. Australian Journal of Crop Science 2013; 7:1293-1301. 
[73] Ali Y, Aslam Z, Ashraf MY, Tahir GR. Effect of salinity on chlorophyll concentration, leaf area, yield and yield components of rice genotypes grown under saline environment. International Journal of Environmental Science and Technology 2004; 1:221-225.

[74] Chunthaburee S, Sanitchon J, Pattanagul W, Theerakulpisut P. Effects of salt stress after late booting stage on yield and antioxidant capacity in pigmented rice grains and alleviation of the salt-induced yield reduction by exogenous spermidine. Plant Production Science 2015; 18:32-42.

[75] Arsa IGBA, Ariffin, Aini N, Lalel HJD. Evaluation of grain yield and aroma of upland rice (Pare Wangi var.) as response to soil moisture and salinity. Current Agriculture Research 2016; 4:35-46.

[76] Chen H, Jiang JG. Osmotic adjustment and plant adaptation to environmental changes related to drought and salinity. Environmental Reviews 2010; 18:309-319.

[77] Teh CY, Mahmood M, Shaharuddin NA, Ho CL. In vitro rice shoot apices as simple model to study the effect of $\mathrm{NaCl}$ and the potential of exogenous proline and glutathione in mitigating salinity stress. Plant Growth Regulation 2015; 75:771-781.

[78] Nounjan N, Theerakulpisut P. Effects of exogenous proline and trehalose on physiological responses in rice seedlings during salt-stress and after recovery. Plant Soil and Environment 2012; 58(7): 309-315.

[79] Bhusan D, Das DK, Hossain M, Murata Y, Hoque MA. Improvement of salt tolerance in rice (Oryza sativa L.) by increasing antioxidant defense systems using exogenous application of proline. Australian Journal of Crop Science 2016; 10:50-56.

[80] Deivanai S, Xavier R, Vinod V, Timalata K, Lim OF. Role of exogenous proline in ameliorating salt stress at early stage in two rice cultivars. Journal of Stress Physiology and Biochemistry 2011; 7:157-174.

[81] Theerakulpisut P, Gunnula W. Exogenous sorbitol and trehalose mitigated salt stress damage in salt-sensitive but not salt-tolerant rice seedlings. Asian Journal of Crop Science 2012; 4:165-170.

[82] Ryu H, Cho Y. Plant hormones in salt stress tolerance. Journal of Plant Biology 2015; 58:147-155.

[83] Li X, Yang M, Chen H, Qu L, Chen F, Shen S. Abscisic acid pretreatment enhances salt tolerance of rice seedlings: proteomic evidence. Biochimica et Biophysica Acta 2010; 1804: 929-940.

[84] Gurmani AR, Bano A, Khan SU, Din J, Zhang JL. Alleviation of salt stress by seed treatment with abscisic acid (ABA), 6-benzylaminopurine (BA) and chlormequat chloride (CCC) optimizes ion and organic matter accumulation and increases yield of rice (Oryza sativa L.). Australian Journal of Crop Science 2011; 5:1278-1285.

[85] Javid MG, Sorooshzadeh A, Sanavy SAMM, Allahdadi I, Moradi F. Effects of the exogenous application of auxin and cytokinin on carbohydrate accumulation in grains of rice under salt stress. Plant Growth Regulation 2011; 65:305-313. 
[86] Kim SK, Son TK, Park SY, Lee IJ, Lee BH, Kim HY, Lee SC. Influences of gibberellin and auxin on endogenous plant hormone and starch mobilization during rice seed germination under salt stress. Journal of Environmental Biology 2006; 27(2): 181-186.

[87] Sharma I, Ching E, Saini S, Bhardwaj R, Pati PK. Exogenous application of brassinosteroid offers tolerance to salinity by altering stress responses in rice variety Pusa Basmati-1. Plant Physiology and Biochemistry 2013; 69:17-26.

[88] Anuradha S, Rao SSR. Effect of brassinosteroids on salinity stress induced inhibition of seed germination and seedling growth of rice (Oryza sativa L.). Plant Growth Regulation 2001; 33:151-153.

[89] Kang DJ, Seo YJ, Lee JD, Ishii R, Kim KU, Shin DH, Park SK, Jang SW, Lee IJ. Jasmonic acid differentially affects growth, ion uptake and abscisic acid concentration in salt-tolerant and salt-sensitive rice cultivars. Journal of Agronomy \& Crop Science 2005; 191: 273-282.

[90] Misratia KM, Ismail MR, Oad FC, Hanafi MM, Puteh A. effect of salinity and alleviating role of gibberellic acid $\left(\mathrm{GA}_{3}\right)$ for enhancement of rice yield. International Journal of Chemical, Environmental \& Biological. 2013; 1(2):330-334.

[91] Bai X, Yang L, Tian M, Chen J, Shi J, Yang Y, Hu X. Nitric oxide enhances desiccation tolerance of recalcitrant Antiaris toxicaria seeds via protein $S$-nitrosylation and carbonylation. PLoS ONE 2011; 6:e20714.

[92] Hasanuzzaman M, GillSS, Fujita M. Physiological role of nitricoxidein plants grown under adverse environmental conditions. In: Tuteja N, Gill SS (eds) Plant acclimation to environmental stress. New York: Springer; 2013. pp. 269-322. doi:10.1007/978-1-4614-5001-6_11

[93] Habib N, Ashraf M, Ahmad MSA. Enhancement in seed germinability of rice (Oryza sativa L.) by pre-sowing seed treatment with nitric oxide (NO) under salt stress. Pakistan Journal of Botany 2010; 42:4071-4078.

[94] Uchida A, Jagendorf AT, Hibino T, Takabe T. Effects of hydrogen peroxide and nitric oxide on both salt and heat stress tolerance in rice. Plant Science 2002; 163:515-523.

[95] Semida WM. Hydrogen peroxide alleviates salt-stress in two onion (Allium cepaL.) cultivars. American-Eurasian Journal of Agricultural and Environmental Sciences 2016; 16:294-301.

[96] Petrov VD, Van Breusegem F. Hydrogen peroxide-a central hub for information flow in plant cells. AoB Plants 2012; pls014. doi:10.1093/aobpla/pls014

[97] Wang X, Hou C, Liu J. Hydrogen peroxide is involved in the regulation of rice (Oryza sativa L.) tolerance to salt stress. Acta Physiologiae Plantarum 2013; 35:891.

[98] Habib N, Ashraf M. Nitric oxide regulated improvement in growth, antioxidant defense system and yield of rice plants grown under salinity. Journal of Plant Pathology \& Microbiology 2016. doi:10.4172/2157-7471.C1.003

[99] Montilla-Bascon G, Rubialesa D, Altabellabc T, Prats E. Free polyamine and polyamine regulation during pre-penetration and penetration resistance events in oat against crown rust (Puccinia coronata f. sp. avenae). Plant Pathology 2016; 65:392-401. 
[100] Kusano T, Berberich T, Tateda C, Takahashi Y. Polyamines: essential factors for growth and survival. Planta 2008; 228:367-381.

[101] Kubiś J, Floryszak-Wieczorek J, Arasimowicz-Jelonek M. Polyamines induce adaptive responses in water deficit stressed cucumber roots. Journal of Plant Research 2014; 127:151-158.

[102] Dobrovinskaya OR, Muñiz J, Pottosin II. Inhibition of vacuolar ion channels by poly amines. The Journal of Membrane Biology 1999; 167:127-140.

[103] Shabala S, Cuin TA, Pottosin I. Polyamines prevent $\mathrm{NaCl}$-induced $\mathrm{K}^{+}$efflux from pea mesophyll by blocking non-selective cation channels. FEBS Letters 2007; 581:1993-1999.

[104] Zhao F, Song CP, He J, Zhu H. Polyamines improve $\mathrm{K}^{+} / \mathrm{Na}^{+}$homeostasis in barley seedlings by regulating root ion channel activities. Plant Physiology 2007; 145:1061-1072.

[105] Ndayiragije A, Lutts S. Do exogenous polyamines have an impact on the response of a salt-sensitive rice cultivar to $\mathrm{NaCl}$ ? Journal of Plant Physiology 2006; 163:506-516.

[106] Ndayiragije A, Lutts S. Exogenous putrescine reduces sodium and chloride accumulation in NaCl-treated calli of the salt-sensitive rice cultivar I Kong Pao. Plant Growth Regulation 2006; 48:51-63.

[107] Chattopadhayay MK, Tiwari BS, Chattopadhyay G, Bose A, Sengupta DN, Ghosh B. Protective role of exogenous polyamines on salinity-stressed rice (Oryza sativa) plants. Physiologia Plantarum 2002; 116:192-199.

[108] Quinet M, Alexis N, Isabella L, Beatrice L, Christine C, Dupont-G SL. Putrescine differentially influences the effects of salt stress on polyamine metabolism and ethylene synthesis in rice cultivars differing salt resistance. Journal of Experimental Botany 2010; 61:2719-2733.

[109] Saleethong P, Sanitchon J, Knog-ngern K, Theerakulpisut P. Pretreatment with spermidine reverse inhibitory effects of salt stress in two rice (Oryza sativa L.) cultivars differing in their tolerance. Asian Journal of Plant Science 2011; 10:245-254.

[110] Paweena S, Jirawat S, Kanlaya K, Piyada T. Effects of exogenous spermidine (Spd) on yield, yield-related parameters and mineral composition of rice (Oryza sativa L. ssp. indica) grains under salt stress. Australian Journal of Crop Science 2013; 7:1293-1301.

[111] Chunthaburee S, Sanitchon J, Pattanagul W, Theerakulpisut P. Alleviation of salt stress in seedlings of black glutinous rice by seed priming with spermidine and gibberellic acid. Notulae Botanicae Horti Agrobotanici Cluj-Napoca 2014; 42:405-413.

[112] Roychoudhury A, Basu S, Sengupta D. Amelioration of salinity stress by exogenously applied spermidine or spermine in three varieties of indica rice differing in their level of salt tolerance. Journal of Plant Physiology 2011; 168:317-328.

[113] Hasanuzzaman M, Nahar K, Fujita M. Silicon and selenium: two vital trace elements in conferring abiotic stress tolerance to plants. In: Parvaiz A, Rasool S (eds) Emerging 
technologies and management of crop stress tolerance, vol. 1-Biological techniques. New York: Academic Press; 2014. pp. 375-420.

[114] Iqbal M, Aslam M. Effect of Zn application on rice growth under saline condition. International Journal of Agriculture and Biology 1999; 1:362-365.

[115] Mehmood EUH, Kausar R, Akram M, Shahzad SM. Is boron required to improve rice growth and yield in saline environment? Pakistan Journal of Botany 2009; 41: 1339-1350.

[116] Zayed BA, Salem AKM, El Sharkawy HM. Effect of different micronutrient treatments on rice (Oryza sativa L.) growth and yield under saline soil conditions. World Journal of Agricultural Sciences 2011; 7:179-184.

[117] Farooq MA, Saqib ZA, Akhtar J. Silicon-mediated oxidative stress tolerance and genetic variability in rice (Oryza sativa L.) grown under combined stress of salinity and boron toxicity. Turkish Journal of Agriculture and Forestry 2015; 39:718-729.

[118] Farooq MA, Saqib ZA, Akhtar J, Bakhat HF, Pasala R-K, Dietz K-J. Protective role of silicon (Si) against combined stress of salinity and boron (B) toxicity by improving antioxidant enzymes activity in rice. Silicon 2015. doi:10.1007/s12633-015-9346-z

[119] Mahdieh MN, Habibollahi MR, Amirjani MH, Abnosi M, Ghorbanpour. Exogenous silicon nutrition ameliorates salt-induced stress by improving growth and efficiency of PSII in Oryza sativa L. cultivars. Journal of Soil Science and Plant Nutrition 2015; 15:1050-1060.

[120] Naim A. Mitigation of salt stress in rice by exogenous application of selenium. M.S. Thesis, Department of Agronomy, Sher-e-Bangla Agricultural University, Dhaka, Bangladesh.

[121] Venkatesh J, Park SW. Role of L-ascorbate in alleviating abiotic stresses in crop plants. Botanical Studies 2014; 55:38.

[122] Wang R, Liu S, Zhou F, Ding, Hua C. Exogenous ascorbic acid and glutathione alleviate oxidative stress induced by salt stress in the chloroplasts of Oryza sativa L. Zeitschrift für Naturforschung C 2014; 69:226-236.

[123] Alhasnawi AN, Che Radziah CMZ, Kadhimi AA, Isahak A, Mohamad A, Yusoff WMW. Enhancement of antioxidant enzymes activities in rice callus by ascorbic acid under salinity stress. Biologia Plantarum 2016. doi:10.1007/s10535-016-0603-9

[124] Alhasnawi AN, Kadhimi AA, Isahak A, Mohamad A, Yusoff WMW, Che Radziah CMZ. Exogenous application of ascorbic acid ameliorates detrimental effects of salt stress in rice (MRQ74 and MR269) seedlings. Asian Journal of Crop Science 2015; 7:186-196.

[125] Barus WA, Rauf A, Rosmayati, Hanum C. Improvement of salt tolerance in some varieties of rice by ascorbic acid application. International Journal of Scientific \& Technology Research 2015; 4:235-237.

[126] Ozfidan-Konakci C, Yildiztugay E, Kucukoduk M. Protective roles of exogenously applied gallic acid in Oryza sativa subjected to salt and osmotic stresses: effects on the total antioxidant capacity. Plant Growth Regulation 2015; 75(1):219-234. 
[127] Sobahan MA, Arias CR, Okuma E, Shimoishi Y, Nakamura Y, Hirai Y, Mori IC, Murata $\mathrm{Y}$. Exogenous proline and glycinebetaine suppress apoplastic flow to reduce $\mathrm{Na}^{+}$uptake in rice seedlings. Bioscience Biotechnology and Biochemistry 2009; 73:2037-2042.

[128] Rahman MS, Miyake H, Takeoka Y. Effect of exogenous glycinebetaine on growth and ultrastructure of salt-stressed rice seedlings (Oryza sativa L.). Plant Production Science $2002 ; 5: 33-44$.

[129] Kim YH, Khan AL, Waqas M, Shim JK, Kim DH, Lee KY, Lee IJ. Silicon application to rice root zone influenced the phyto hormonal and antioxidant responses under salinity stress. Journal of Plant Growth Regulation 2014; 33:137-149. doi:10.1007/ s00344-013-9356-2

[130] Shi Y, Wanga Y, Flowers TJ, Gonga H. Silicon decreases chloride transport in rice (Oryza sativa L.) in saline conditions. Journal of Plant Physiology 2013; 170:847-853.

[131] Saeedipour S. Salinity tolerance of rice lines related to endogenous abscisic acid (ABA) level synthesis under stress. African Journal of Plant Science 2011; 5:628-633. 